\title{
5-10 Yaş Grubu Çocuklara Yönelik Geliştirilmiş Çalışma Belleği Ölçeğinin Geçerlik ve Güvenirliği
}

\author{
Cevriye Ergül ${ }^{1}$, Çağla Özgür Yılmaz ${ }^{2}$, Ergül Demir ${ }^{3}$ \\ ${ }^{1}$ Özel Eğitim Bölümü, Eğitim Bilimleri Fakültesi, Ankara Üniversitesi, Ankara, Türkiye \\ ${ }^{2}$ Özel Eğitim Bölümü, Eğitim Fakültesi, Aksaray Üniversitesi, Aksaray, Türkiye \\ ${ }^{3}$ Eğitim Bilimleri Bölümü, Eğitim Bilimleri Fakültesi, Ankara Üniversitesi, Ankara, Türkiye
}

Sorumlu Yazar: Cevriye Ergül, cergul@ankara.edu.tr

Makale Türü: Araştırma Makalesi

Araştırma/Proje Desteği: Bu çalışma TÜBİTAK tarafından desteklenmiştir (Proje No: 215K027).

Bilgilendirme: Bu çalışmanın deneme uygulamaları Doç. Dr. Cevriye Ergül danışmanlığında Çağla Özgür Yılmaz tarafından gerçekleştirilen yüksek lisans tez çalışması kapsamında yürütülmüştür.

Kaynak Gösterimi: Ergül, C., Çağla, Ö.Y., \& Ergül, D. (2018). 5-10 Yaş Grubu Çocuklara Yönelik Geliştirilmiş Çalışma Belleği Ölçeğinin geçerlik ve güvenirliği. Eğitimde Kuram ve Uygulama, 14(2), 187-214. doi:10.17244/eku.427280

\section{Validity and Reliability of the Working Memory Scale for Children Aged 5-10 Years \\ Cevriye Ergül ${ }^{1}$, Çağla Özgür Y1lmaz ${ }^{2}$, Ergül Demir ${ }^{3}$ \\ ${ }^{1}$ Department of Special Education, Faculty of Educational Sciences, Ankara University, Ankara, Turkey \\ ${ }^{2}$ Department of Special Education, Faculty of Education, Aksaray University, Aksaray, Turkey \\ ${ }^{3}$ Department of Educational Sciences, Faculty of Educational Sciences, Ankara University, Ankara, Turkey}

Corresponding Author: Cevriye Ergül, cergul@ankara.edu.tr

Article Type: Research Article

Funding: This study was supported by TÜBİTAK (Project No: 215K027).

Acknowledgement: The pilot implications of this study was performed within the master thesis carried out by Çağla Özgür Yılmaz under the supervision of Assoc. Prof. Cevriye Ergül.

To Cite This Article: Ergül, C., Çağla, Ö. Y., \& Ergül, D. (2018). 5-10 Yaş Grubu Çocuklara Yönelik Geliştirilmiş Çalışma Belleği Ölçeğinin geçerlik ve güvenirliği. Eğitimde Kuram ve Uygulama, 14(2), 187-214. doi:10.17244/eku.427280 


\title{
5-10 Yaş Grubu Çocuklara Yönelik Geliştirilmiş Çalışma Belleği Ölçeğinin Geçerlik ve Güvenirliği
}

\author{
Cevriye Ergül ${ }^{1}$, Çağla Özgür Yılmaz ${ }^{2}$, Ergül Demir ${ }^{3}$ \\ ${ }^{1}$ Özel Eğitim Bölümü, Eğitim Bilimleri Fakültesi, Ankara Üniversitesi, Ankara, Türkiye \\ ORCID: https://orcid.org/0000-0001-6793-6469 \\ 2 Özel Ĕ̈itim Bölümü, Eğitim Fakültesi, Aksaray Üniversitesi, Aksaray, Türkiye \\ ORCID: https://orcid.org/0000-0002-1279-8967 \\ ${ }^{3}$ Eğitim Bilimleri Bölümü, Eğitim Bilimleri Fakültesi, Ankara Üniversitesi, Ankara, Türkiye \\ ORCID: https://orcid.org/0000-0002-3708-8013
}

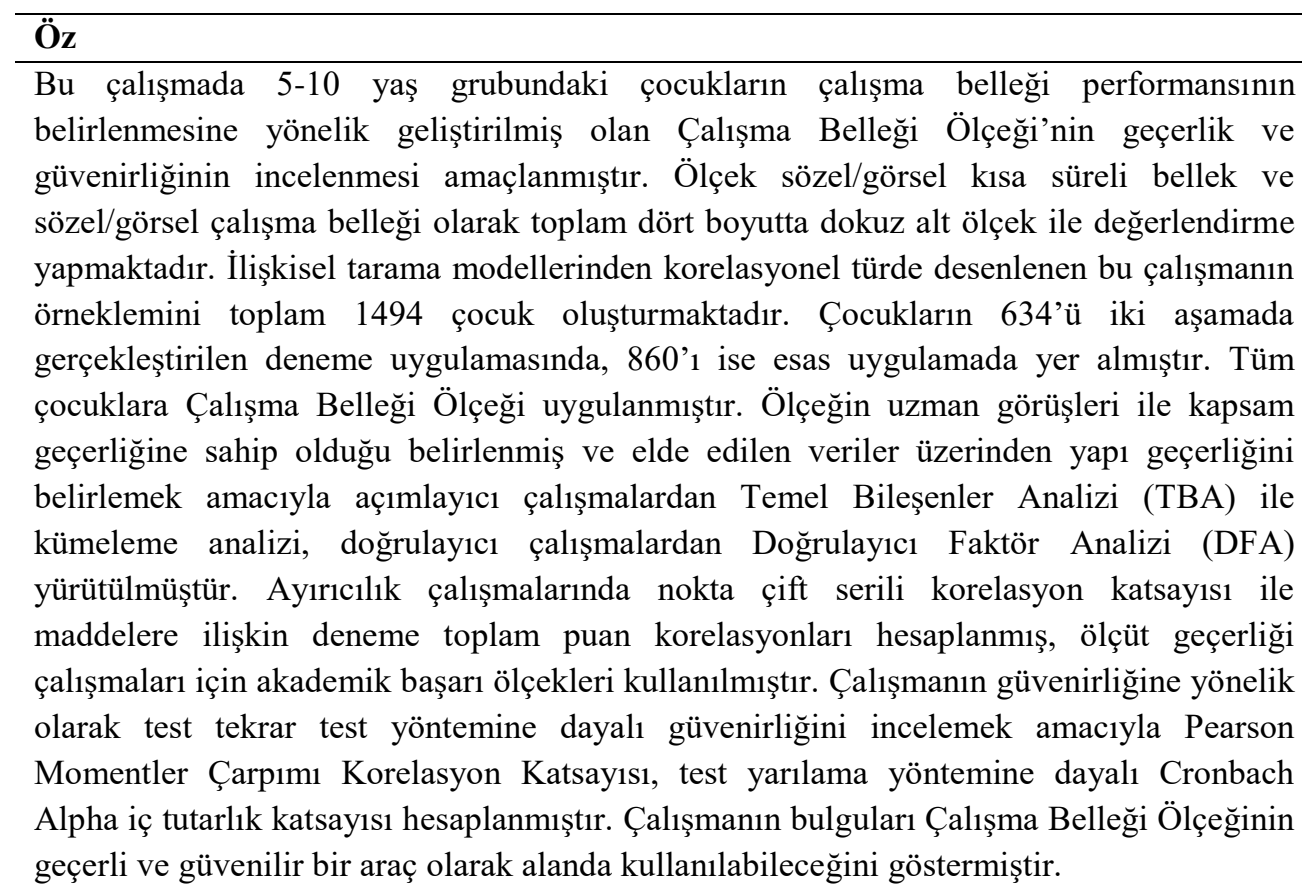

\section{Validity and Reliability of the Working Memory Scale for Children Aged 5-10 Years}

Makale Bilgisi

Anahtar Kelimeler: Çalışma belleği, Geçerlik, Güvenirlik, Ölçek

Makale Geçmişi:

Geliş: 02 Temmuz 2017

Düzeltme: 21 Mart 2018

Kabul: 25 Mayıs 2018

Makale Türü: Araştırma Makalesi

\begin{abstract}
In this study, it was aimed to examine the reliability and validity of the Working Memory Scale developed to determine the performance of working memory for children in the age group of 5-10 years. The scale evaluates with nine subtests in total four dimensions as verbal / visual short-term memory and verbal / visual working memory. A correlational model from relational screening models was used in the study. A total of 1494 children constituted the sample, 634 of whom were involved in the two trial stages and 860 were involved in the main application. All children were administered the Working Memory Scale. Content validity of the scale was examined by means of expert opinions. To determine the construct validity a principal content analysis, a cluster analysis and a confirmatory factor analysis were performed. For the discriminant validity, point-biserial correlation coefficients and the item-total score correlations were calculated. Academic Achievement Scales were used for criterion validity. In order to determine the test-retest reliability, a Pearson product-moment correlation coefficient was calculated while a Cronbach's alpha internal consistency coefficient was calculated for the split-half reliability. The findings of the study show that the Working Memory Scale can be used in the field as a valid and reliable tool.
\end{abstract}

Article Info

Keywords: Reliability, Scale, Validity, Working memory

Article History:

Received: 02 July 2017

Revised: 21 March 2018

Accepted: 25 May 2018

Article Type: Research Article 


\section{Giriş}

Bellek, yaşam için çok önemli eşsiz bir bilişsel yapıdır. Öğrenmenin gerçekleştirilmesi ve kişisel anıların oluşturulması bellek fonksiyonları sayesinde gerçekleşir (Dehn, 2008; 2010). Bu bilişsel yapı kendi içinde duyusal bellek, kısa süreli bellek, çalışma belleği ve uzun süreli bellek gibi farklı bileşenleri içermektedir (Thorn \& Page, 2009). Duyusal bellek, duyular tarafından alınan çevresel uyaranları anlık olarak tutan yapıdır ve bu anlık zaman diliminde uyaranların ancak bir kısmı girdi olarak kısa süreli belleğe ulaşır (Dehn, 2010). Kısa süreli bellek bilginin pasif bir şekilde tutulmasını sağlayan yapıdır (Archibald \& Gathercole, 2006). Çalışma belleği bilginin geçici olarak depolanıp aynı zamanda kodlanıp işlendiği sınırlı bellek sistemi olarak tanımlanmıştır (Baddaley, 2007; Baddaley \& Hitch, 1974; Chiappe, Hasher, \& Siegel, 2000; Rajendran, Alloway, \& Archibald, 2009). Uzun süreli bellek ise bilginin kalıcı olarak depolandığı pasif bir sistemdir (Dehn, 2010).

Son yıllarda belleğe ilişkin çalışmaların özellikle çalışma belleği üzerinde yoğunlaştığı dikkati çekmektedir (De Weerdt, Desoete, \& Roeyers, 2013; Harrison, Shipstead, \& Engle, 2015; Marton \& Eichorn, 2014; Nyman vd., 2010; Peng \& Fuchs, 2017; Pimperton \& Nation, 2014; Ricker \& Cowan, 2014; Schweppe \& Rummer, 2014). Tarihsel süreç içerisinde farklı şekillerde tanımlansa da çalışma belleği en sık üç bileşenli bir yapı olarak tanımlanmaktadır. Baddaley ve Hitc'in (1974) çok bileşenli modeline göre (bkz. Şekil 1.1.) çalışma belleği fonolojik döngü ve görsel-mekansal kayıt defteri alt sistemleri ile bu sistemleri kontrol eden merkezi yönetici ana fonksiyonundan oluşmaktadır.

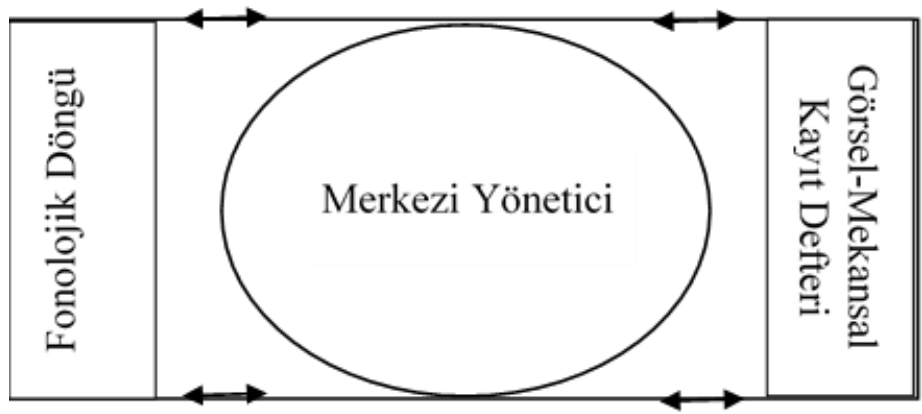

Şekil 1. Baddaley ve Hitch (1974) Tarafından Geliştirilen Çok Bileşenli Çalışma Belleği Modeli

Fonolojik döngü sözel bilginin geçici olarak tutulduğu sınırlı kapasite olarak tanımlanmaktadır (Baddaley, 2000; 2007; Baddaley, Gathercole, \& Papagno, 1998). Sözel kısa süreli bellek olarak da ifadelendirilen fonolojik döngü sözel girdiyi sadece birkaç saniye boyunca tutabilmektedir. Bu arada artikülasyon döngüsü devreye girer, yani sözel girdi iç ses yoluyla tekrar edilir ise bilgi hatırlanmaya devam edilir (Baddaley, 2000; 2007; Dehn, 2008; Tercan, Ergin, \& Amado, 2012). Aksi takdirde, bilgi kısa süre içerisinde silikleşmekte ve unutulmaktadır (Dehn, 2008; Gathercole, Pickering, Knight, \& Stegmann, 2004). Tekrarlanması gereken bilginin miktarı arttıkça da tekrarlama zorlaştığı için unutma kolaylaşmaktadır (Baddaley, 2000; 2007). Görsel-mekansal kayıt defteri, fonolojik döngü ile benzer şekilde işleyen ve çalışma belleğinin her türlü görsel bilgiyi kısa süreliğine depolayan bileşenidir (Baddaley, 2000; 2007; Baddaley \& Logie, 1999). Görsel veya mekansal depolama işlevini gerçekleştiren bu bileşen ile materyaller renk ve şekil olarak görsel depolanırken, konumları da mekânsal olarak depolanmaktadır (Baddaley, 1994; Hu, Hitch, Baddaley, Zang, \& Allen, 2014). Unutma hızı ise uyaranların karmaşıklığına ve görülme süresine bağlı olarak değişmektedir (Baddaley, 2007). Üçüncü bileşen olan merkezi yönetici de fonolojik döngü ve görsel mekânsal kayıt defterini kontrol ederek bu alt sistemlerdeki bilgileri işlemleyen ve çalışma belleğindeki tüm işlemleri koordine eden yapıdır (Baddaley, 2007; Dehn, 2008). Odaklanma ve dikkatin yöneltilmesi, uzun süreli bellekteki temsillerin etkinleştirilmesi, kodlama ve geri çağırma işlemlerini gerçekleştirmektedir (Baddaley \& Loggie, 1999; Dehn, 2008; Gathercole vd., 2004). Ek olarak, bilginin işlemlenmesi için uygun stratejilerin seçilmesi ve farklı kaynaklardan bilgilerin bütünleştirilmesi görevlerini de yerine getirmektedir (Dehn, 2008). Çok bileşenli modeldeki bu üç temel yapıya ek olarak çalışma belleği ile uzun süreli bellek arasındaki etkileşimi açıklamak üzere sonraki yıllarda modele olaysal tampon olarak isimlendirilen dördüncü bir bileşen de eklenmiştir (Baddaley, 2000; 2007). Buna karşın, üç bileşenli model halen değerlendirmelerde temel alınan model olmaya devam etmektedir (Alloway \& Alloway, 2010; 
Jerman, Reynolds, \& Swanson, 2012; Mammarella, Lucangeli, \& Cornoldi, 2010; Nyman vd., 2010; Peng \& Fuchs, 2017).

Çalışma belleği bireyin tüm yaşantısını etkileyen ve öğrenme üzerinde oldukça etkili bir yapıdır (Baddaley \& Hitch, 1974; Rajendran vd., 2009; Tercan vd., 2012). Öğrenme, bilginin depolanmasını, kodlanıp işlenmesini ve uzun süreli bellekle etkileşim içinde olunmasını gerektirmektedir (Dehn, 2008). Bu açıdan çalışma belleğinin kapasitesi ve etkin bir şekilde çalışması öğrenme düzeyini belirlemekte ve tüm bilişsel görevlere ilişkin performansı yordamaktadır (Alloway \& Alloway, 2010; Rajendran vd., 2009; Engle, 2002). Çok sayıda çalışmada çalışma belleği performansı ile dil gelişimi, okuma, okuduğunu anlama, yazma ve matematik başarısı arasında güçlü ilişkiler olduğu belirtilmektedir (Berninger \& Richards, 2002; Bull \& Scerif, 2001; Chiappe vd., 2000; De Weerdt vd., 2012; Kroesbergen, Van't Noordende, \& Kolkman 2012; Swanson, 2000; 2011). Örneğin, çalışma belleği dil becerilerinin gelişiminde etkili temel yapılardan biridir (Crain, Shankweiler, Macaruso, \& Bar-Shalom, 1990; Dehn, 2008; Gathercole vd., 2004). Özellikle fonolojik döngünün hem anadilde hem de ikinci bir dilde yeni sözcüklerin öğrenilmesinde önemli bir rolü olduğu ifade edilmektedir (Akoğlu, 2011; Baddeley, 1996; Service, 1992). Dili anlarken ve konuşurken ayrıca sözcüklerin ve cümlelerin depolanması, kodlanması ve geri getirilmesi gibi eş zamanlı birçok bellek işleminin gerçekleştirilmesi gerekmektedir (Dehn, 2008; Gathercole vd., 2004). Okurken ise harflerin sıralı bir şekilde seslere dönüştürülmesi, geçici olarak depolanması ve sonrasında tümünün sırasıyla seslendirilerek sözcükler oluşturulması yine fonolojik döngü ile gerçekleştirilmektedir (De Weerdt vd., 2012; Swanson, Kehler, \& Jerman, 2009; Tercan vd., 2012). Çalışma belleği okuduğunu anlamada da çok etkin olarak gereksinim duyulan bir yapıdır. Anlama süreci sözcüklerin kodlanması, bu sözcüklerin anlamlandırılması ve cümle bazında birleştirilip daha büyük parçalar elde edilmesi gibi karmaşık bellek işlemlerini gerektirmektedir. Benzer olarak, matematik fonolojik döngü, görselmekansal kayıt defteri ve merkezi yönetici işlevlerini gerektiren beceriler içermektedir. (Bull \& Scerif, 2001; De Weerdt vd., 2012; Gathercole \& Pickering, 2000; Passolunghi \& Siegel, 2004; Swanson \& Sachse-lee, 2001). Say1 kavramının geliştirilmesi, aritmetik işlem yapma, problem çözme ve geometri gibi temel matematik becerileri çalışma belleğinin tüm bileşenlerinin etkin bir şekilde kullanılmasını gerektirmektedir (Geary, Hoard, Byrd-Craven, Nugent, \& Numtee, 2007; Kroesbergen vd., 2012; Passolunghi \& Siegel, 2004). Bununla birlikte sinif etkinlikleri de not alma, not alırken diğer konuşmacıları dinleme, karmaşık yönergeleri takip etme, yabancı sözcükleri çözümleme, zihinden cümleler oluşturma, yeni bilgileri işlemleme ve daha önce depolanmış bilgiler ile bütünleştirme gibi depolama ve eşzamanlı işlemlemeyi gerektiren çok sayıda beceri ile gerçekleştirilmektedir (Engle, 1996). Bu nedenle, tüm bu işlemlerden sorumlu olan çalışma belleğinde bir yetersizlik olduğunda söz konusu becerilerdeki problemler de kaçınılmaz olmaktadır. Yapılan çalışmalarda dilde ve akademik becerilerde yetersizlik yaşayan çocukların normal gelişim gösteren akranlarına göre çalışma belleği kapasitelerinin daha sınırlı olduğu ve bilgiyi daha yavaş ve yetersiz bir şekilde işlemleyebildikleri ve depoladıkları bulunmuştur (Alloway \& Archibald, 2008; Dehn, 2008). Diğer taraftan, erken yaşlarda ortaya koyulan çalışma belleği performansı ilerideki akademik başarıyı güçlü bir şekilde yordamaktadır (Alloway, 2010; Bull \& Scerif, 2001; Rajendran vd., 2009; Swanson, 2011). Çalışma belleğinin öğrenmeyi zeka puanlarına göre daha yüksek düzeyde yordadı̆̆ 1 da alanyazında bildirilen bulgular arasındadır (Alloway \& Alloway, 2010). Bu bağlamda, yetersiz çalışma belleği performansı olan çocukların erken dönemde belirlenerek müdahale programları ile desteklenebilmeleri için çalışma belleği performansının değerlendirilmesi büyük önem taşımaktadır (Alloway \& Alloway, 2010; Kroesbergen vd., 2012; Swanson, 2000; 2006).

\section{Çalışma Belleği Performansının Değerlendirilmesi}

Özellikle yurtdışı alanyazında çalışma belleğinin değerlendirilmesine yönelik çok sayıda aracın geliştirilmiş olduğu görülmektedir. $\mathrm{Bu}$ araçlar incelendiğinde büyük bir çoğunluğunun ve en yaygın olarak kullanılanlarının (örn., Automated Working Memory Assessment-AWMA: Alloway, Gathercole, Willis, \& Adams, 2004 ve Working Memory Test Battery for Children-WMTB-C: Pickering \& Gathercole, 2001) Baddaley ve Hitc'in (1974) çok bileşenli çalışma belleği modelini temel aldıkları gözlenmektedir. Buna göre, araçlar fonolojik döngü, görsel mekansal kayıt defteri ve merkezi yönetici bileşenlerinin değerlendirilmesine yönelik görevler içermektedir. Fonolojik döngü ve görsel-mekansal kayıt defterinin değerlendirilmesinde bilginin pasif olarak saklanmasını gerektiren bellek aralı̆g 1 (memory span) görevleri kullanılmaktadır (Dehn, 2008). Bellek aralığı; ardışık sırada sunulan bilginin kişi tarafından doğru hatırlanabilen maksimum miktarını ifade etmektedir (Gathercole, 1999). Genel olarak, fonolojik döngü rakamların, harflerin ve sözcüklerin kısa süreli depolanarak sunulduğu sırada hatırlanmasını gerektiren basit bellek 
aralığı (simple span) görevleri ile değerlendirilmektedir (Alloway \& Alloway, 2010; Dehn, 2008; Pickering \& Gathercole, 2001). Anlamsız sözcük hatırlama da sıklıkla kullanılan fonolojik döngü görevlerinden biridir (Akoğlu \& Acarlar, 2014; Dehn, 2008) ve bu görevi gerçekleştirirken uzun süreli bellek ve önceki deneyimlerden yararlanılamaması nedeniyle ayırt ediciliğinin özellikle daha güçlü olduğu ifade edilmektedir (Dehn, 2008). Çok sayıda testte kullanıldığı belirlenen anlamsız sözcük hatırlama tek heceli veya hece sayısı gittikçe artan çok heceli anlamsız sözcükler ile gerçekleştirilebilmektedir (Alloway vd., 2004; Gathercole, 2001; Holmes \& Adams, 2006). Görsel-mekansal kayıt defterinin değerlendirilmesinde de fonolojik döngü ile benzer şekilde basit bellek aralı̆̆ 1 görevleri kullanılmaktadır (Dehn, 2008). Bu görevler genelde matrislerle oluşturulan desenleri ve farklı şekillerde yerleştirilmiş küp ve blokların mekansal konumlarının hatırlanmasını içerir (Alloway \& Alloway; 2010; Dehn, 2008). Değerlendirmelerde kayıt defterinin görsel boyutu daha çok matris görevleri ile açıklanırken, mekânsal boyutu blok görevleriyle açıklanmaktadır (Baddaley, 2007). Merkezi yöneticinin değerlendirilmesine yönelik görevlerde ise depolamayla birlikte eş zamanlı işlemleme gerektiren iki görevli (dual-task) karmaşık bellek aralığı (complex span) görevleri kullanılmaktadır (Dehn, 2008). Bunlar içerisinde en sık kullanılanı giderek artan aralıktaki bir dizi rakamın geriye doğru tekrar edilmesinin istendiği geriye rakam hatırlama görevidir (Alloway \& Alloway, 2010; Archibald \& Gathercole, 2006; De Weerdt vd., 2012; Holmes vd., 2009; Passolunghi \& Siegel, 2004). Bununla birlikte artan sayıda sunulan bir dizi cümlenin son sözcüklerinin hatırlanmasına dayanan dinlediğini hatıllama (listening recall) görevi merkezi yöneticiyi değerlendirmek için sıklıkla tercih edilen diğer bir görevdir (Alloway \& Alloway, 2010; Alloway vd., 2006; Archibald \& Gathercole, 2006; De Weerdt vd., 2012; Gathercole vd., 2004). Diğer taraftan, çalışma belleğinin değerlendirilmesine yönelik kullanılan çok sayıda araç merkezi yöneticiyi genellikle sözel görevler ile değerlendirirken, bazı araçlar (örn., AWMA) merkezi yöneticiye ilişkin daha güçlü ve güvenilir bilgiler elde edilebilmesi için hem sözel hem de görsel-mekansal görevler içermektedir. Bu amaçla artan sayıdaki dizilerde farklı olan şekil/resimlerin veya aynı desen üzerinde farklı yerleştirilmiş nokta/şekillerin ayırt edilerek dizi tamamlandıktan sonra da farklı olanların yerinin veya pozisyonunun sırasıyla hatırlanması gibi görsel bilginin depolanması ve eş zamanlı olarak işlemlenmesini gerektiren görevler sıkça kullanılmaktadır. Bununla birlikte merkezi yöneticinin görselmekansal boyutunu değerlendirmek amacıyla karmaşık içeriğe sahip iki farklı resmin sırayla gösterilmesinden sonra ikinci resimde birinci resimden farklı olan, değişen ya da eklenen şekillerin hatırlanmasını içeren (picture memory) görevler ya da bir labirent üzerindeki rotayı hatırlamayı içeren görevler de kullanılmaktadır (Dehn, 2008).

WMTB-C ve AWMA gibi çalışma belleğini değerlendirmek üzere yaygın olarak kullanılan araçlar incelendiğinde ise, bu araçların çalışma belleğinin bileşenlerine yönelik olarak farklı sayılarda görevler kullanarak değerlendirmeyi gerçekleştirdikleri görülmektedir. Bunlardan WMTB-C çoklu bileşen modeli temelinde fonolojik döngü, görsel-mekansal kayıt defteri ve mekansal yönetici bileşenlerine yönelik dokuz görev/alt test içermektedir. Fonolojik döngü ölçümleri için rakam hatırlama (digit recall), sözcük listesi hatırlama (word list recall), anlamsız sözcük listesi hatırlama (nonword list recall) ve sözcük listesi eşleştirme (word list matching - bir sözcük listesinin daha önce sunulduğu sırada mı yoksa farklı sırada mı sunulduğunun hatırlanması) görevleri bulunmaktadır. Görselmekansal kayıt defteri ölçümleri için blok hatırlama (block recall) ve labirent hatırlama (mazes memory) görevleri bulunmaktadır (Gathercole vd., 2004). Blok hatırlama görevinde dokuz adet rastgele yerleştirilmiş bloktan oluşan ve bir tahta üzerinde sunulan dizinin tekrar üretilmesi istenirken, labirent hatırlama görevinde, kırmızı bir yolun çizildiği bir labirentte çocuktan önce eliyle kırmızı çizginin üzerinden gitmesi ve sonra kırmızı çizginin olmadığı labirentte kırmızı çizgiyi sunulduğu şekliyle çizmesi istenmektedir (Dehn, 2008). WMTB-C merkezi yönetici ölçmeye yönelik ise dinlediğini hatılama (listening recall), hesaplayarak hatırlama (counting recall) ve geriye rakam hatırlama (backward digit recall) görevlerini içermektedir. $\mathrm{Bu}$ görevler depolamanın yanında eş zamanlı işlem yapmayı gerektiren görevlerdir. Örneğin, dinlediğini hatırlama görevinde bir dizi kısa cümle sunularak çocuktan hızlı bir şekilde cümlenin doğru bir bilgi içerip içermediğini söylemeleri (örn., "Köpek iki ayaklıdır") ve dizi tamamlandıktan sonra dizideki tüm cümlelerin son sözcüklerinin sunulan sırada hatırlanması beklenmektedir. Hesaplayarak hatırlama görevinde ise çocuklardan kendisine sunulan bir dizi kart üzerindeki kırmızı noktaları sayması ve sonra her karttaki nokta sayısını sunulduğu sıraya göre hatırlaması istenmektedir. Yapılan çalışmalarda WMTB-C'nin geçerliği ve güvenirliği gösterilmiş ve standardizasyonu tamamlanmıştır (Pickering \& Gathercole, 2001). Ek olarak, açımlayıcı ve doğrulayıcı faktör analizleri testin dayandığı çoklu bileşen modelini desteklemiştir. Alanyazında çalışma belleğinin değerlendirilmesini içeren çok sayıdaki çalışma da WMTB-C kullanarak değerlendirmelerini gerçekleştirmiştir (ClairThompson \& Gathercole, 2006; De Weerdt vd., 2012; Gathercole, Brown, \& Pickering, 2003; Holmes \& Adams, 
2006; Peng \& Fuchs, 2017). Çalışma belleği performansının belirlenmesinde sıklıkla kullanılan diğer bir araç ise AWMA (Alloway, 2007)'dır. AWMA, çocukların çalışma belleği performanslarının hızlı ve etkili bir şekilde belirlemek amacıyla sınıf öğretmenleri gibi uzman olmayan uygulayıcılar için standartlaştırılmış bir araçtır (Alloway, Gathercole, Kirkwood, \& Elliot, 2008). AWMA'nın birçok alt testi, WMTB-C'nin alt testleriyle benzer olmakla birlikte yapı olarak WMTB-C'den faklıdır ve birçok özgün alt testi içermektedir (Dehn, 2008). Ayrıca, WMTB- C'den farklı olarak Baddaley'in merkezi yönetici kavramının yerine çalışma belleğini ve bunun alt sistemleri olarak sözel çalışma belleği ve görsel-mekansal çalışma belleği kavramlarını kullanır. AWMA sözel ve görsel- mekansal çalışma belleğini ayrı olarak ölçen ilk test olma özelliğine sahiptir (Alloway, Gathercole, \& Pickering, 2006). Bununla birlikte çalışma belleğini sözel kısa süreli bellek, görsel-mekansal kısa süreli bellek, sözel çalışma belleği ve görsel mekansal çalışma belleği olmak üzere dört alanda üçer görev/alt test ile değerlendirir (Alloway \& Alloway, 2010; Alloway vd., 2008; Dehn, 2008). Bilgisayar tabanlı olan bu test toplamda 12 alt testten oluşmakla birlikte uygulama kolaylığ 1 açısından dört alt testlik kısa bir formu da bulunmaktadır. Sözel kısa süreli bellek testi için; rakam hatırlama (digit span), sözcük hatırlama (word recall) ve anlamsız sözcük hatırlama (nonword recall) görevleri, görsel-mekansal kısa süreli bellek testi için; blok hatırlama (block recall), labirent hatırlama (mazes recall) ve nokta matris (dot matris) görevleri, sözel çalışma belleği testi için; dinlediğini hatırlama (listening recall), geriye rakam hatırlama (backward digit recall) ve hesaplayarak hatırlama (counting recall) görevleri, görsel- mekansal çalışma belleği testi için ise Bay X (Mr X), farklı olanı eleme (odd one out) ve mekansal uzam (spatial span) görevleri bulunmaktadır. Görsel-mekansal çalışma belleği görevlerinden Bay X ve mekansal uzam, 360 derece döndürülen şekillerin mekânsal konumlarının benzerliğini değerlendirme ve onlar üzerinde işaretlenen yerlerin hatırlama gibi eş zamanlı işlemler içerir (Alloway vd., 2008). Farklı olanı eleme görevi ise bir dizi kutuda sunulan üç farklı şekilden farklı olanın ayırt edilmesi ve yerlerinin dizi tamamlandıktan sonra sunulan sırada hatırlanmasını gerektirmektedir (Rajendran vd., 2009). AWMA'nın da yapılan çalışmalar ile geçerli ve güvenilir bir araç olduğu gösterilmiş ve doğrulayıcı faktör analizi ile dört faktörlü yapısı desteklenmiştir (Alloway vd., 2006).

Alanyazında çalışma belleğinin değerlendirilmesine yönelik kullanıldığı belirlenen diğer araçlar ise Swanson Cognitive Processing Test (S-CPT; Swanson, 1995), Wechsler Memory Scales- Third edition (WMS-III; Wechsler, 1997), Children's Memory Scale (CMS; Cohen, 1997), Test of Memory and Learning- Second Edition (TOMAL-2; Reynolds \& Noress, 2007) ve Wide Range Assessment of Memory and Learning- Second Edition (WRAML-2; Adams \& Sheshow, 2003)'dir. Araçlar incelendiğinde çoğunlukla WMTB-C ve AWMA'ya benzer görevler kullanıldığı dikkati çekmektedir (Dehn, 2008).

Son yıllarda Türkiye'de çalışma belleğine olan ilginin arttığı ve çalışma belleğinin etkilerini inceleyen araştırmaların yapıldığı gözlenmektedir (Alp \& Özdemir, 2007; Altun \& Çevik, 2012; Kafadar, 2004; Kesikçi \& Amado, 2005; Sayar \& Turan, 2012; Tercan vd., 2012). Bu çalışmalara bakıldığında genel olarak çalışma belleğini ölçmek amacıyla ters sayı dizilerinin kullanıldığı görülmektedir. Bu bağlamda araştırmacılar tarafından kullanılan en yaygın standart test, WISC-R zeka ölçeğinin çalışma belleğini ölçmeye yönelik alt testi olan sayı dizileri iken (Alp \& Özdemir, 2005; Kesikçi \& Amado, 2005) kullanılan diğer bir test Türkçe'ye uyarlaması yapılan "Görsel İşitsel Sayı Dizisi Testi” (GISD; Yalın \& Karakaş, 1994)'dir. GISD 5-12 yaş aralığındaki çocuklarda fonolojik döngü (sözel kısa süreli bellek) performansını ölçmeyi hedefleyen bir araçtır ve yazılı veya sözel olarak sunulan sayı dizilerinin yine yazılı veya sözlü olarak tekrarlanması görevini içermektedir. Diğer bir araç ise lisans düzeyindeki öğrencilerle Türkçe uyarlama çalışmaları yapılan bilgisayar tabanlı bir program olan ve hem çalışma belleğini sözel ve görsel boyutta ölçmede hem de belleği geliştirmede eğitim aracı olarak kullanılabileceği ifade edilen "Brain Workshop 4.8.1"dir. Araçta görsel-mekansal, işitsel ve görsel-işitsel olmak üzere çeşitli şekillerde sunulan bir seri uyarıcının bireyden $n$ adım sonra tekrarlamasının istendiği bir görev (n-geri görevi) kullanılmaktadır (Altun \& Çevik, 2012). Doğan (2011) tarafından geliştirilen bir araçta ise çalışma belleğini ölçmek amacıyla çift görev işlemlerin yer aldığı "cümle-sayı uzamı" ve "sayı-sözcük uzamı" görevleri oluşturulmuştur. Cümle-sayı uzamı görevinde katılımcılardan önce cümleleri, sonra sonuna eklenen sayıları okumaları istenmiş ve dizi tamamlandıktan sonra cümlelerin sonunda yer alan sayıları sunulduğu sıra ile hatırlamaları beklenmiştir. Sayı-sözcük uzamı görevinde ise katılımcılardan önce sayıları sonra sayıların sonuna eklenen sözcükleri okumaları istenmiş ve dizi tamamlandıktan sonra da sayıların sonunda yer alan sözcükleri doğru sırada hatırlamaları beklenmiştir. Bu araçta, çalışma belleğinin bir diğer bileşeni olan görselmekansal kayıt defterini ölçmek amacıyla da kağıt katlama görevi oluşturulmuştur. Bu görevde kağıt her dizide birden üçe kadar artırılarak katlanmış ve her katlama sonunda katlanan kağıdın tam ortasına farklı geometrik şekillerde delik 
açılmıştır. Sonrasında kağıdın katları açılarak hangi şeklin ortaya çıktığı gösterilmiştir. Katılımcılardan ise her dizi sonunda kağıtların ortasına açılan şekilleri hatırlamaları istenmiştir. Aracın güvenirlik çalışmasına ilişkin veriler bildirilmiş olmakla birlikte geçerlik verileri sunulmamıştır.

Alanyazın incelendiğinde çalışma belleğinin sadece belirli bir bileşenini ölçmeyi amaçlayan araçların da geliştirilerek geçerlik ve güvenirlik çalışmalarının yapıldığı görülmektedir. Çalışmalarda fonolojik döngüye yönelik olarak en çok sayı, sözcük ve anlamsız sözcük dizilerinin kullanıldığı dikkati çekmektedir (Akoğlu \& Acarlar, 2014; Tercan vd., 2012). Akoğlu ve Acarlar (2014) fonolojik döngüyü ölçmek amacıyla 1-4 heceli anlamsız sözcükler ile anlamsız sözcük tekrarı görevini oluşturmuşlar ve 3-9 yaş arası 152 çocuk ile sinırlı düzeyde geçerlik ve güvenirlik çalışması gerçekleştirmişlerdir. Bir diğer çalışma da Tercan ve diğerleri (2012), yine fonolojik döngüye yönelik olarak anlamsız sözcük tekrarı ve anlamsız bir sözcük içeren cümle tekrarı görevlerini geliştirmişler ve 74 çocuğa uygulayarak maddelerin iç tutarlılığı üzerinden güvenirlik analizini gerçekleştirmiştir. Anlamsız sözcük tekrarı görevinin kullanıldığı başka bir çalışmada ise dört heceli anlamsız sözcüklerin tekrarı fonolojik döngüyü ölçmek amacıyla kullanmıştır (Kesikçi \& Amado, 2005). Bununla birlikte çalışmada bu araca ilişkin geçerlik-güvenilirlik çalışmalarına yer verilmemiştir.

Alanyazın incelemesi Türkiye'de genel olarak çalışma belleğine yönelik ilginin ve çalışmaların sayısının artmakta olduğunu (örn., Akoğlu, 2011; Karakelle \& Ertuğrul, 2012; Kesikçi \& Amado, 2005; Tercan vd., 2012) ve çalışmalarda buna yönelik araçlar/görevler geliştirildiğini, buna karşın, geliştirilen araçların/görevlerin hem çalışma belleğinin tüm bileşenlerini içerecek şekilde oluşturulmadığ 1 hem de geçerlik ve güvenirlik çalışmalarının sınırlı olduğu dikkati çekmektedir. Oysa çalışma belleği ile öğrenme ve akademik başarı arasındaki güçlü ilişki göz önünde bulundurulduğunda, çalışma belleğini ölçmeyi içerecek temel araştırmaların yapılabilmesi ve yetersiz çalışma belleği performansı olan çocukların erken dönemde belirlenebilmesi açısından kapsamlı, geçerli ve güvenilir araçların geliştirilmesine olan ihtiyaç son derece açıktır. Bu kapsamda, bu çalışmada Baddaley ve Hitch'in (1974) Çok Bileşenli Modeli’ni temel alarak geliştirilmiş Çalışma Belleği Ölçeğinin geçerlik ve güvenirliğin incelenmesi amaçlanmıştır. Bu genel amaç doğrultusunda aşağıdaki sorulara yanıt aranmıştır:

1. Geliştirilen Çalışma Belleği Ölçeğinin geçerliği ne düzeydedir? Bu kapsamda;

a. Yapı geçerliği ne düzeydedir?

b. Madde-toplam puan korelasyonlarına dayalı olarak ayırıcılık anlamında geçerliği ne düzeydedir?

c. Ölçüt geçerliği ne düzeydedir?

2. Geliştirilen Çalışma Belleği Ölçeğinin güvenirliği ne düzeydedir? Bu kapsamda ölçme aracının;

a. Test- tekrar- test yöntemine dayalı devamlılık/kararlılık anlamında güvenirliği ne düzeydedir?

b. Test yarılama yöntemine dayalı iç tutarlılık anlamında güvenirliği ne düzeydedir?

\section{Yöntem}

\section{Katılımcılar}

İlişkisel tarama modellerinden korelasyonel türde desenlenen bu çalışmanın örneklemini, Ankara ilinin yedi merkez ilçesinde (Altındağ, Mamak, Çankaya, Yenimahalle, Etimesgut, Sincan ve Keçiören), bağımsız anaokulu ve ilkokullar bünyesinde öğrenim gören 5-10 yaş grubundaki (anasınıfı - 4. sınıf) 1494 çocuk oluşturmuştur. Bu çocuklardan 634'ü iki aşamada gerçekleştirilen çalışmanın deneme uygulamasında yer alırken 860'1 esas uygulamada yer almıştır. Örneklem seçiminde tabakalı küme örnekleme yöntemi, örnekleme birimi olarak ise okullar kullanılmıştır. Tüm ilçeler üç sosyo-ekonomik düzeye göre sınıflandırılmış ve deneme uygulaması her tabakadan (alt, orta, üst) seçkisiz atama yoluyla 11 okul olmak üzere toplamda 33 okul ile yürütülürken, esas uygulama her tabakadan (alt, orta, üst) seçkisiz atama yoluyla 10 okul olmak üzere toplamda 30 okul ile yürütülmüştür. Okullarda seçkisiz atama yoluyla her sınıf düzeyinden 1'er şube ve her şubeden de deneme uygulamasında dörder çocuk, esas uygulamada altışar çocuk seçkisiz atama yoluyla belirlenerek çalışmaya dahil edilmiştir. Çalışma grubunu oluşturacak öğrencilerin normal gelişim göstermesi, herhangi bir yetersizlik tanısı almamış olması ve anadilinin Türkçe olmasına dikkat edilmiştir. Cinsiyet değişkeni dikkate alınarak her okuldaki öğrencinin eşit sayıda kız ve erkek öğrenci olacak şekilde seçilmiştir. Belirlenen öğrencilerin katılım kriterlerini karşılamadığı durumda aynı sınıftan başka bir öğrenci yine seçkisiz atama yoluyla belirlenerek çalışmaya dahil edilmiştir. Çalışmada anaokulundan 127; 1. sinıftan 118; 2. sınıftan $126 ; 3$. sınıftan 132 ve 4. sınıftan 131 öğrenci katılmıştır. Ölçeğin ölçüt geçerliği kapsamında öğrencilerin akademik 
başarılarını belirlemek üzere görüşlerine başvurulan toplam 32 öğretmen de akademik başarı ölçeklerini doldurarak çalışmaya katkıda bulunmuşlardır.

\section{Veri Toplama Araçları}

\section{Aile Bilgi Formu}

Çalışmaya katılan çocukları betimsel olarak tanımlamaya ve demografik özelliklerine ilişkin bilgi almaya yönelik form araştırmacılar tarafından geliştirilmiştir. Bu bilgi formunda, çocukların yaş, cinsiyet, gelişimsel bilgilerine yönelik sorular ile ailenin eğitim durumuna ilişkin bilgiler yer almaktadır. Bilgi formları değerlendirmeden önce öğretmen aracılığıyla ailelere ulaştırılarak doldurulmaları sağlanmıştır.

\section{Uzman Görüş̈̈ Formu}

ÇBÖ ile akademik başarı ölçeklerinin kapsam geçerliğini belirlemek amacıyla araştırmacılar tarafindan önceden hazırlanmış test maddelerine (her alt ölçeğe ilişkin maddelerin 5-10 yaş grubu çocukların düzeyine uygun olup olmadı̆̆ı, sözcüklerin, cümlelerin veya şekillerin anlaşılır olup olmadığı ve seslerin veya şekillerin art arda veya tekrarlı bir şekilde kullanılıp kullanılmadığı) ilişkin üçlü likert tipi değerlendirme formu geliştirilerek dört farklı uzmandan 1 (Uygun), 2 (Düzeltilmeli), 3 (Uygun Değil) şeklinde puanlamaları istenmiştir.

\section{Akademik Başarı Ölçekleri}

Çalı̧̧maya katılan çocukların akademik başarılarını ölçmek ve bu ölçme sonuçlarını ÇBÖ’ne yönelik ölçüt temelli geçerlik çalışmalarında kullanmak amacıyla araştırmacılar tarafından geliştirilmiştir. Akademik başarı ölçekleri anasınıfı, birinci ve ikinci sınıf öğrencilerine yönelik üç ayrı ölçek ile üçüncü ve dördüncü sınıf öğrencilerine yönelik bir ölçek olmak üzere toplam 4 ölçekten oluşmaktadır. Ölçeklerin geliştirilmesi aşamasında MEB 2015 müfredat programı incelenmiş ve her sınıf düzeyinde yer alan gelişim basamakları temel alınmıştır. Bu kapsamda oluşturulan ölçekler, dil, bilişsel, Türkçe ve matematik becerilerini içermektedir. Ölçeklere ilişkin geçerlik ve güvenirlik çalışmaları toplam 624 çocukla gerçekleştirilmiştir. Ölçeğin yapı geçerliği çalışmaları olarak açımlayıcı faktör analizi (temel bileşenler analizi) (AFA) kullanılmıştır. Verilerin faktör analizine uygunluğu incelenmiş ve ölçekler için KMO değerleri sırasıyla $.91, .90, .90$ ve .96 ve Bartlett testi sonuçları $\mathrm{X}^{2}=3737.20,3588.16,4292.03,9104.13(\mathrm{df}=35,40$, $35,37, p<.05$ ) olarak bulunmuş ve faktör analizine uygun olduğu görülmüştür. Anasınıfı, 1., 2. ve 3-4. sinıflar için madde öz değerlerinin ise sırasıyla .39-.85, .46-.75, .70-.89 ve .73-.89 arasında değiştiği gözlenmiştir. Tüm ölçeklerin tek boyutlu ve yine sirasılyla $\% 73, \% 64, \% 80$ ve $\% 81$ açılanan varyans düzeylerine sahip oldukları görülmüştür. Faktör yük değerleri .62-.92, .68-.89, .84-.94 ve .85-.94 arasında değişmektedir. Ölçeklerin madde toplam puan korelasyonları .71 ile .94 arasında değişirken ve madde ayırt edicilik ortalamaları .80 'dir. Ölçeğin test yarılama yöntemine dayalı iç tutarlılığı katsayıları 98 ile .99 arasında değişmektedir.

\section{Çalışma Belleği Ölçeği}

Çalışma Belleği Ölçeği (ÇBÖ) anasınıfından 4. sınıfa kadar olan dönemdeki öğrencilerin çalışma belleği performanslarının belirlenmesi amacıyla geliştirilmiş bir araçtır. Ölçeğin geliştirilme sürecinde ilk olarak yukarıda da belirtildiği gibi aynı model temelinde geliştirilen ve diğer ülkelerde kullanılan standart testler detaylı bir şekilde incelenmiştir. Yapılan incelemeler sonucunda AWMA'da olduğu gibi fonolojik döngü ve görsel mekansal kayıt defterine ek olarak merkezi yöneticiyi de iki alt boyutta değerlendiren bir yaklaşımın daha güvenilir bir çalışma belleği ölçümü ile sonuçlanacağı düşünülmüştür. Ardından bu boyutların değerlendirilmesi sürecinde kullanılan görevler incelenmiştir. Bu kapsamda tüm standart testlerde kullanılan farklı boyutlara yönelik görevler için daha detaylı bir inceleme gerçekleştirilerek bu testler içerisinde en sık kullanılan görevler belirlenmiştir. Sonuç olarak ÇBÖ’nin sözel bellek ve görsel bellek alt alanlarına yönelik olarak sözel/görsel kısa süreli bellek ve sözel/görsel çalışma belleği olarak toplam dört boyutta değerlendirme yapacak bir araç olmasına karar verilmiştir. Sözel kısa süreli bellek boyutu; Rakam Hatırlama, Sözcük Hatırlama ve Anlamsız Sözcük Hatırlama olarak üç alt ölçek, görsel kısa süreli bellek boyutu; Desen Matrisi ve Blok Hatırlama, Sözel Çalışma Belleği boyutu; Geriye Rakam Hatırlama ve İlk Sözcüğü Hatırlama, Görsel Çalışma belleği boyutu; Farklı Olanı Seçme ve Mekansal Ayırt Etme olarak ikişer alt ölçek ile ÇBÖ dört alt boyut ve dokuz alt ölçek ile oluşturulmuştur. Her bir alt ölçek gittikçe artan sayıda dizileri içeren maddelerden ve her maddede de iki denemeden oluşmaktadır. Her alt ölçek aynı zamanda iki örnek uygulamayı içermektedir. Alt ölçeklerin uygulanması sırasında her bir maddede yer alan diziler sırasıyla ve anlaşılır bir şekilde çocuğa sunulmakta ve çocuk her bir maddedeki denemelerden en az birisinde başarılı olduğu durumda bir sonraki maddeye geçilmektedir. Her iki denemede de başarısız olduğu durumda ise o alt ölçek sonlandırılarak sonraki alt ölçeğe geçilmektedir. Çocukların doğru sırada tekrarladıkları / işaretledikleri her bir dizi için bir puan verilmektedir. 
ÇBÖ’nin ölçtüğü alt alanlar, alt boyutlar ve içerdiği alt ölçeklere ilişkin toplam madde sayıları Çizelge 1'de sunulmuştur.

Çizelge 1. ÇBÖ’nin İçerdiği Alt ölçeklere İlişkin Toplam Madde Sayıları

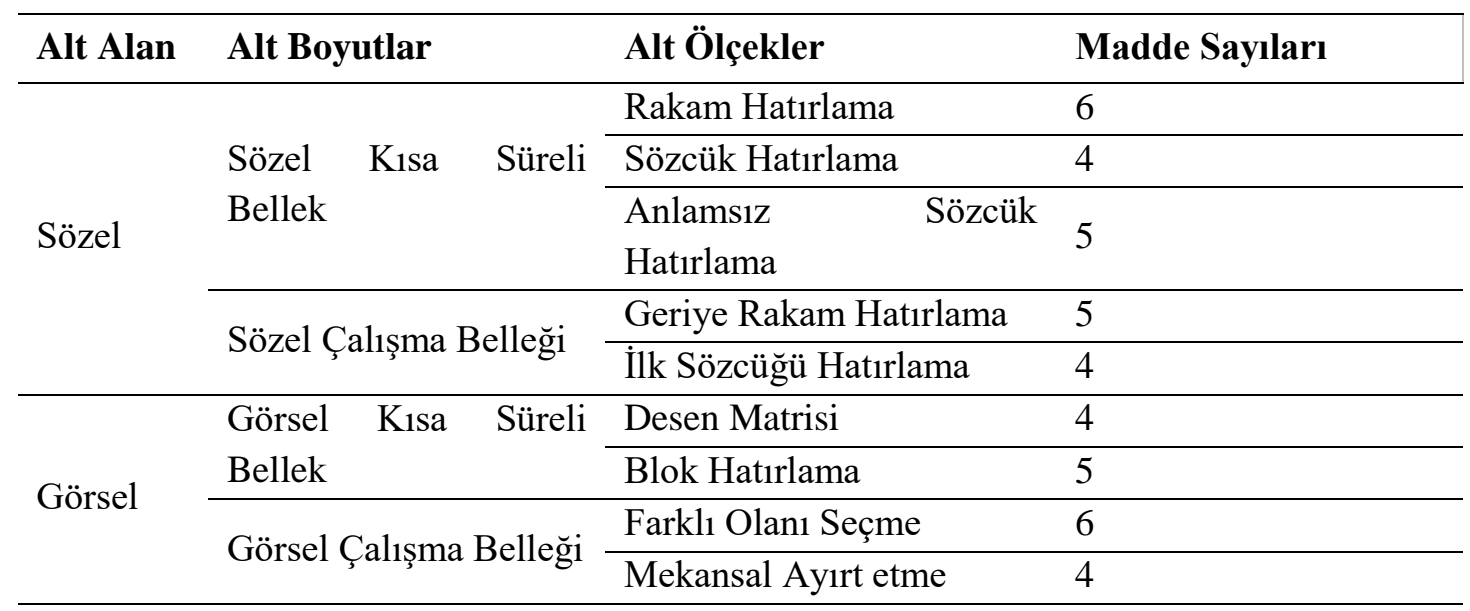

Sözel kısa süreli bellek alanında, ÇBÖ’ne ilişkin sözel kısa süreli bellek alt boyutunda Rakam Hatırlama, Sözcük hatırlama ve Anlamsız Sözcük Hatırlama olmak üzere üç alt ölçek yer almaktadır:

Rakam Hatırlama $(R H)$ alt ölçeğinde çocuklardan kendilerine sunulan rakam dizilerini hatırlamaları ve aynı sırada tekrarlamaları beklenmektedir. Gittikçe artan sayıda (3-8) rakam dizilerini içeren toplamda 6 maddeden ve her madde ise iki denemeden oluşmaktadır. Rakamların her biri alt ölçekte sadece bir kez kullanılmıştır. Testin uygulanması sırasında her bir dizideki rakamlar sırasıyla ve anlaşılır bir şekilde (ortalama olarak saniyede bir rakam) çocuğa sunulmakta ve çocuktan duyduğu rakamları duyduğu sıra ile tekrarlamaları istenmektedir.

Sözcük Hatırlama (SH) alt ölçeğinde çocuklardan kendilerine sunulan sözcük dizilerini hatırlamaları ve aynı sırada tekrarlamaları beklenmektedir. Gittikçe artan sayıda (3-6) sözcük dizileri içeren toplamda 4 maddeden ve her madde ise iki denemeden oluşmaktadır. Kullanılan sözcükler tek heceli (ünsüz-ünlü-ünsüz) sözcükler arasından seçilmiş, çocukların günlük hayatta karşılaştıkları anlamlı sözcükler olmasına dikkat edilmiştir. Her biri alt ölçekte sadece bir kez kullanılmıştır. Testin uygulanması sırasında dizideki sözcükler sırasıyla ve anlaşılır bir şekilde (ortalama olarak saniyede bir sözcük) çocuğa sunulmakta ve çocuktan duyduğu sözcükleri duyduğu sira ile tekrarlamaları istenmektedir.

Anlamsız Sözcük Hatırlama (ASH) alt ölçeğinde çocuklardan kendilerine sunulan anlamsız sözcük dizilerini hatırlamaları ve aynı sırada tekrarlamaları beklenmektedir. Gittikçe artan sayıda (2-6) anlamsız sözcük dizileri içeren toplamda 5 maddeden ve her madde ise iki denemeden oluşmaktadır. Sözcüklerin her biri alt ölçekte sadece bir kez kullanılmıştır. Anlamsız sözcükler SH alt ölçeğinde yer alan anlamlı sözcüklerin ters çevrilmesi yoluyla oluşturulmuştur. Ters çevrildiğinde de anlamlı olduğu veya çocukların karşılaşma olasılığı olan yabancı dillerdeki sözcüklerin seslendirmelerini yansıtması durumunda sözcüklerde yeni düzenlemelere gidilmiştir. Testin uygulanması sırasında her bir dizideki sözcükler sırasıyla ve anlaşılır bir şekilde (ortalama saniyede bir sözcük olacak şekilde) çocuğa sunulmakta ve çocuktan duyduğu sözcükleri duyduğu sıra ile tekrarlamaları istenmektedir.

Görsel kısa süreli bellek alanında, ÇBÖ’ne ilişkin görsel kısa süreli bellek alt boyutunda Desen Matrisi ve Blok Hatırlama olmak üzere iki alt ölçek yer almaktadır:

Desen Matrisi Alt (DM) alt ölçeğinde çocuklardan 5x5'lik bir karelaj üzerinde kendilerine sunulan kırmızıya boyanmış kareleri hatırlamaları ve önlerindeki $5 \times 5$ 'lik boş karelaj üzerinde işaretlemeleri beklenmektedir. İçerdiği kımızı kare sayısı gittikçe artan (2-5) toplamda 4 maddeden ve her madde ise iki denemeden oluşmaktadır. Testin uygulanması sırasında her bir desen dizisi üç saniye süre ile çocuğa sunulmakta ve çocuktan gösterilen kırmızı karelerin tümünün yerini işaretlemeleri istenmektedir.

Blok Hatırlama (BH) alt ölçeğinde çocuklardan gri renkte dokuz bloktan oluşan bir zemin üzerinde her gösterildiğinde farklı konumlandırılmış sarı bloğun yerini, dizinin tamamlanmasının ardından hatırlamaları ve kendilerine gösterildiği sırada önlerindeki dokuz blokluk boş zemin üzerinde işaretlemeleri beklenmektedir. İçerdiği sarı blok sayısı gittikçe artan (2-6) toplamda 5 maddeden ve her madde ise iki denemeden oluşmaktadır. Testin 
uygulanması sırasında her bir blok dizisi (ortalama olarak saniyede bir blok) çocuğa sunulmakta ve çocuktan gördüğü sarı blokların tümünü gösterilen sıra ile işaretlemeleri istenmektedir.

Sözel çalışma belleği alanında, ÇBÖ’ne ilişkin sözel çalışma belleği alt boyutunda Geriye Rakam Hatırlama ve İlk Sözcüğü Hatırlama olmak üzere iki alt ölçek yer almaktadır:

Geriye Rakam Hatırlama (GRH) alt ölçeğinde çocuklardan kendilerine sunulan rakam dizilerini hatırlamaları ve ters sırada tekrarlamaları beklenmektedir. Gittikçe artan sayıda (2-6) rakam dizileri içeren toplamda 5 maddeden ve her madde ise için iki denemeden oluşmaktadır. Rakamların her biri alt ölçekte bir kez kullanılmıştır. Testin uygulanması sırasında her bir dizideki rakamlar sırasıyla ve anlaşılır bir şekilde (ortalama olarak saniyede bir rakam) çocuğa sunulmakta ve çocuktan duyduğu rakamları ters sıra ile tekrarlamaları istenmektedir.

İlk Sözcü̆ğü Hatırlama (ISSH) alt ölçeğinde çocuklardan kendilerine sunulan cümleyi önce anlam olarak doğru olup olmadığını değerlendirmeleri ve ardından cümlelerin ilk sözcüklerini hatırlayarak dizinin tümü sunulduktan sonra duydukları sırada tekrarlamaları beklenmektedir. Bu görev için yabancı kaynaklı çalışmalarda cümlelerin son sözcügünün hatırlanması istenirken, Türkçe cümle yapısına bağlı olarak sadece cümlelerin ilk sözcüklerinin yalın halde bulunma olasılığı daha yüksek olduğu için cümlelerin ilk sözcüklerinin hatırlanması istenmiştir (Babayiğit \& Stainthorp, 2009; 2011). Gittikçe artan sayıda (2-5) cümle dizileri toplamda 4 maddeden ve her madde ise iki denemeden oluşmaktadır. Testin uygulanması sırasında her bir dizideki cümleler sırasıyla ve anlaşılır bir şekilde çocuğa söylenmekte ve çocuktan cümleyi doğru/yanlış olarak değerlendirdikten sonra dizinin tüm cümlelerinin ilk sözcüklerini duyduğu sıra ile tekrarlamaları istenmektedir.

Görsel çalışma belleği alanında, ÇBÖ’ne ilişkin görsel çalışma belleği alt boyutunda Farklı Olanı Seçme ve Mekansal Ayırt Etme olmak üzere iki alt ölçek yer almaktadır:

Farklı Olanı Seçme (FOS) alt ölçeğinde çocuklardan yan yana konumlandırılmış üç kutucuk içerisindeki üç geometrik şekilden farklı olanı seçmeleri ve ardından farklı olan şeklin yerini hatırlayarak dizinin tümü sunulduktan sonra gösterildiği sırada önlerindeki boş kutucuk dizisi üzerinde işaretlemeleri beklenmektedir. Farklı olan şekil aynı olan şekillerin farklı konumlandırılması veya içerdiği çizgilerin farklı yerleştirilmesi yoluyla oluşturulmuştur ve her seferinde farklı sıradaki kutucuğa yerleştirilmiştir. Gittikçe artan sayıda (2-7) kutucuk dizileri toplamda 6 maddeden ve her madde ise iki denemeden oluşmaktadır. Testin uygulanması sırasında her bir kutucuk dizisi (ortalama olarak 35 saniye) çocuğa sunulmakta ve çocuktan her dizide farklı olan şekli seçerek dizinin tamamlanmasının ardından yerlerini gördüğü sıra ile işaretlemeleri istenmektedir.

Mekansal Ayırt Etme (MAE) alt ölçeğinde çocuklardan yan yana konumlandırılmış içi farklı veya aynı desenlerde doldurulmuş iki yıldız şeklini önce aynı/aynı değil olarak değerlendirmeleri ve ardından sağdaki yıldızın her seferinde farklı bir uzantısında konumlandırılmış kırmızı noktaların yerini hatırlayarak dizinin tümü sunulduktan sonra gösterildiği sırada önlerindeki boş yıldız dizisi üzerinde işaretlemeleri beklenmektedir. Gittikçe artan sayıda (25) yıldız dizileri toplamda 4 maddeden ve her madde ise iki denemeden oluşmaktadır. Testin uygulanması sırasında her bir yıldız dizisi sırasıyla ve anlaşı1ır bir şekilde çocuğa sunulmakta ve çocuktan yıldızları aynı/aynı değil olarak değerlendirdikten sonra dizideki tüm kırmızı noktaların yerini gösterilen sıra ile işaretlemeleri istenmektedir.

\section{Verilerin Toplanması}

Çalışma, iki deneme uygulaması ve esas uygulama olmak üzere üç aşamada gerçekleştirilmiştir. Deneme uygulamaları toplam 634 çocuk ile gerçekleştirilirken, esas uygulama 860 çocuk ile gerçekleştirilmiştir. Birinci deneme uygulaması sonunda yapılan analizler sonucunda testte yer alacak maddelere karar verilmiş ikinci deneme uygulaması sonunda yapılan analizler sonucunda ise majör düzeltmeler yapılmış ve esas uygulama 860 çocuk ile gerçekleştirilmiştir.

Araştırma verilerinin toplanmasında özel eğitimde doktora ve yüksek lisans programlarına devam eden beş uygulayıcı görev almıştır. Uygulayıcılar öncelikle birinci dönemin başında iki gün süren ve ölçeğin içeriğine ve uygulanmasına ilişkin bir eğitim almışlardır. Bu eğitim süresince, araştırmacıların örnek uygulamalarını izlemişler, sonra birbirlerine uygulayarak uygulamalarını geliştirmişlerdir. Bu uygulamaları sırasında araştırmacılar tarafından izlenerek uygulamalarına yönelik geribildirim sunulmuştur. Eğitimin tamamlanmasının ardından her bir uygulayıcı her sınıf düzeyinden ikişer çocuğa uygulayarak uygulama yeterliklerini geliştirmişlerdir. Bu uygulamaları sırasında aldıkları video kayıtlar ise sonrasında araştırmacılar tarafından izlenerek uygulama yeterliği kazanıp kazanmadıkları değerlendirilmiştir. Tüm uygulamacıların uygulama yeterliği kazanmalarının ardından bu çalışma kapsamındaki esas uygulamalara başlamışlardır. Her uygulayıcı deneme uygulamaları kapsamında belirlenen 11 okula giderek veri toplama için uygun gün, saat ve ortamı okul yöneticisi veya yöneticinin görevlendirdiği rehber öğretmen ile 
belirlemiştir. Uygun zaman ve ortamın belirlenmesinden sonra uygulayıcı belirlenen çocuklara bireysel olarak ölçeği uygulamıştır. Her alınan öğrenci için sınıf öğretmenlerinden akademik başarı ölçeklerini dikkatlice okuyup doğru bir şekilde doldurmaları istenmiştir. Ayrıca her çocuğun ailesine Aile Bilgi Formu gönderilerek doldurmaları istenmiştir. Aile formları ve akademik başarı ölçekleri bir sonraki gün okula tekrar gidilerek toplanmıştır. Eksik form var ise hatırlatması yapılmış ve hafta içerisinde temin edilerek tüm formların eksiksiz bir şekilde toplanması sağlanmıştır. Esas uygulama için de her uygulayıcı kendisi için belirlenen okullarda veri toplayarak süreci tamamlamışlardır.

\section{Verilerin Analizi}

Verilerin analizinde ÇBÖ’nin kapsam geçerliğini belirlemek için alt ölçekler dört farklı uzmanlık alanında (Ölçme ve Değerlendirme, Okul öncesi, Sınıf Öğretmenliği, Özel Eğitim ve Türkçe) çalışmalarını sürdüren dört öğretim üyesine sunulmuş ve her bir ölçek maddesine ilişkin maddelerin 5-10 yaş grubu çocukların düzeyine uygun olup olmadığına, sözcüklerin, cümlelerin veya şekillerin anlaşılır olup olmadığına ve seslerin veya şekillerin art arda veya tekrarlı bir şekilde kullanılıp kullanılmadığına dair soruları 1 (Uygun), 2 (Düzeltilmeli), 3 (Uygun Değil) şeklinde puanlamaları istenmiştir. Ayrıca uygun görmedikleri maddelere ilişkin niye uygun görmediklerini, önerilerini ve verilen sürelere ilişkin görüşlerini içeren kısa açıklamalar yazmaları da istenmiştir. Uzman grubunun değerlendirmeleri sonucunda geliştirilen ölçeklerin kapsam geçerliğine sahip olduğu belirlenmiş ve elde edilen veriler üzerinden araştırma sorularına cevap aranmıştır. Bu aşamada, çalışmanın geçerliğine yönelik olarak, yapı geçerliğini belirlemek amacıyla açımlayıcı çalışmalardan Temel Bileşenler Analizi (TBA) ile kısmi ihlaller olması durumunda TBA'ni desteklemek amacıyla kümeleme analizi, doğrulayıcı çalışmalardan Doğrulayıcı faktör analizi (DFA) yürütülmüş, ayırıcılık çalışmalarında nokta çift serili korelasyon katsayısı ile maddelere ilişkin deneme toplam puan korelasyonları, ölçüt geçerliği çalışmaları için akademik başarı ölçekleri ile ÇBÖ alt ölçekleri arasında ilişkiyi incelemek amacıyla Pearson Momentler Çarpımı Korelasyon Katsayısı hesaplanmıştır. Çalışmanın güvenirliğine yönelik olarak test tekrar test yöntemine dayalı güvenirliğini incelemek amacıyla Pearson Momentler Çarpımı Korelasyon Katsayısı, test yarılama yöntemine dayalı Cronbach Alpha iç tutarlık katsayısı hesaplanmıştır. Verilerin analizinde SPSS Paket Programı'nın 22. sürümünden yararlanılmıştır.

\section{Bulgular}

$\mathrm{Bu}$ bölümde ÇBÖ’ne ilişkin araştırma soruları birinci deneme uygulaması, ikinci deneme uygulaması ve esas uygulama verileri olmak üzere üç alt başlık altında ve her üç uygulama için geçerlik ve güvenirlik çalışmaları ayrı olarak ele alınmış olup sonuçlar aşağıda sunulmuştur.

\section{ÇBÖ’nin Yapı Geçerliği Çalışmaları}

Birinci ve ikinci deneme uygulaması sonuçları üzerinde yapı geçerliğini belirlemek amacıyla açımlayıcı çalışmalardan Temel Bileşenler Analizi (TBA) ile kısmi ihlaller olması durumunda TBA'ni desteklemek amacıyla kümeleme analizi yürütülmüştür. Kümeleme analizi birimlerin ortak faktör yapılarını göstererek doğru kategorilere sınıflandırılmasını sağlayan bir yöntemdir (Çokluk, Şekercioğlu, \& Büyüköztürk, 2016). Esas uygulama sonuçları üzerinde yap1 geçerliğini belirlemek amacıyla doğrulayıcı çalışmalardan Doğrulayıcı Faktör Analizi (DFA) yürütülmüştür.

\section{Birinci Deneme Uygulamasına İlişkin TBA Sonuçları}

Her bir alt ölçeğin birinci deneme uygulamaları verilerinin öncelikle TBA'ne uygunluğu incelenmiştir. RH, SH, GRH, ASH, İSH, DM, BH, FOS ve MAE alt ölçeklerine ait deneme verilerinin KMO değerleri sırasıyla .75, .75, .65, .74, $.67, .64, .73, .82, .76$ ve Bartlett testi sonuçları sirasiyla $\mathrm{X}^{2}=1122.86,500.70,1140.12,639.40,506.37,812.96$, 1081.64, 1539.69, 1108.32, (df=45,28, 45, 28,28, 28, 28, 45, 66, 28, $p<.05)$ temelinde TBA'ne uygun olduğu değerlendirilmiştir. Tüm alt ölçeklere ait TBA sonuçları Tablo 2'de verilmiştir.

Tablo 2. Çalışma Belleği Alt Ölçekleri için Birinci Deneme Uygulaması TBA Sonuçları

\begin{tabular}{|c|c|c|c|c|c|c|}
\hline \multirow{3}{*}{$\begin{array}{l}\text { Alt } \\
\text { Ölçekle }\end{array}$} & \multirow{3}{*}{$\begin{array}{l}\text { İhmal } \\
\text { Edilen Maddelere } \\
\text { İlişkin } \\
\text { rDenemeler }\end{array}$} & \multirow{3}{*}{$\begin{array}{l}\text { Kalan } \\
\text { Madde } \\
\text { Sayısı }\end{array}$} & \multicolumn{3}{|c|}{ Açıklanan } & \multirow{3}{*}{$\begin{array}{l}\text { Madde } \\
\text { Öz Değerleri }\end{array}$} \\
\hline & & & Düzeyi & Alt & BoyutYük & \\
\hline & & & $(\%)$ & Sayısı & Değerleri & \\
\hline$\overline{\mathrm{RH}}$ & 1.1., 1.2., 8.1., 8.2. & 6 & 69 & 3 & ,62-,90 & ,53-,91 \\
\hline $\mathrm{SH}$ & 1.1.,1.2., 6.1., 6.2 & 4 & 68 & 3 & , 40-,81 & ,42-,71 \\
\hline GRH & 6.1., 6.2., 7.1., 7.2., & $8.1 ., 5$ & 71 & 3 & , 40-,91 & ,59-,94 \\
\hline
\end{tabular}




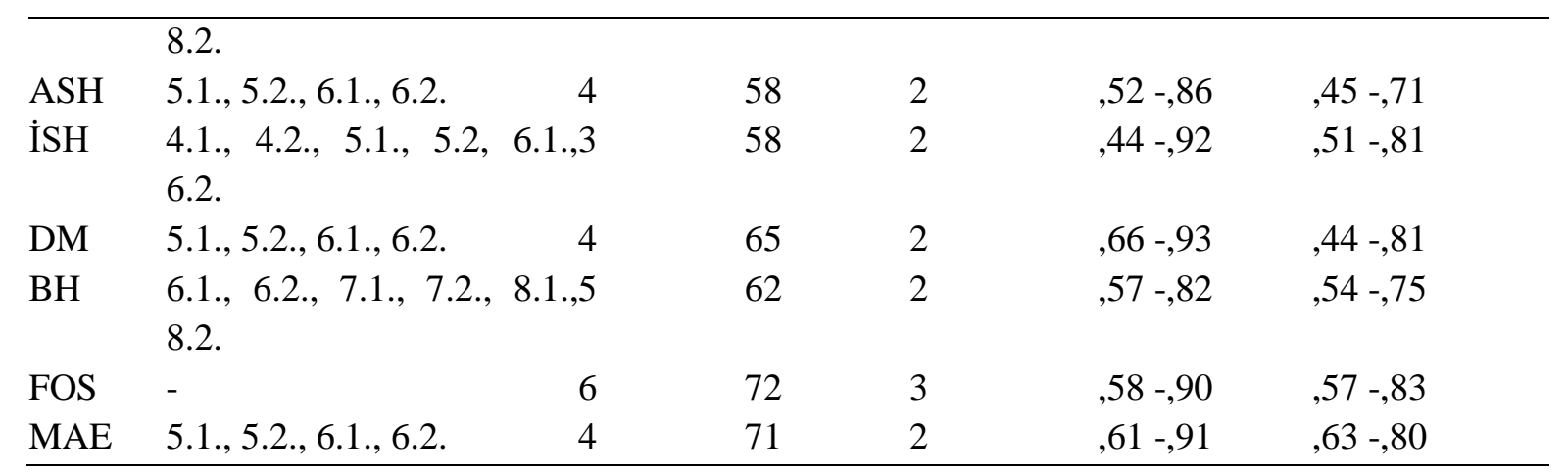

Tablo 2'de görüldüğü gibi faktör yük değerleri açısından binişik madde bulunmamış ve TBA çıktıları tüm alt ölçeklerin yapı geçerliğinin yüksek olduğunu göstermiştir. KMO değerlerinin düşük olması ve örneklemin sinırlılığı sebebiyle TBA sonuçlarını desteklemek üzere GRH, ASH, İSH ve DM alt ölçekleri üzerinde yürütülen kümeleme analizi sonucu elde edilen dendogramlar Şekil 2, 3, 4 ve 5'de verilmiştir.

$\begin{array}{ll}\text { GRH8.1. } & 8.1 . \\ \text { GRH8.2. } & 8.2 . \\ \text { GRH6.1. } & 6.1 . \\ \text { GRH7.1. } & 7.1 . \\ \text { GRH7.2. } & 7.2 . \\ \text { GRH6.2. } & 6.2 . \\ \text { GRH5.2. } & 5.2 . \\ \text { GRH4.2. } & 4.2 . \\ \text { GRH5.1. } & 5.1 . \\ \text { GRH4.1. } & 4.1 . \\ \text { GRH3.1. } & 3.1 . \\ \text { GRH3.2. } & 3.2 . \\ \text { GRH1.1. } & 1.1 . \\ \text { GRH1.2. } & 1.2 . \\ \text { GRH2.1. } & 2.1 . \\ \text { GRH2.2. } & 2.2 . \\ & \end{array}$

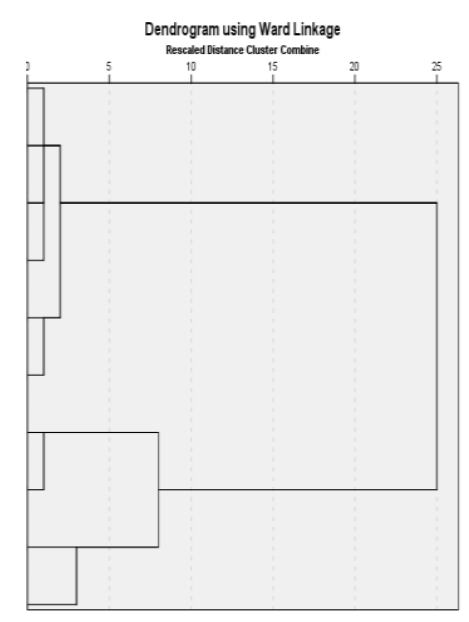

Şekil 2. GRH Madde Alt Boyut Kümelemesi
ASH5.1.5.1.

ASH5.2.5.2.

ASH4.1.4.1.

ASH4.2.4.2.

ASH3.1.3.1.

ASH3.2.3.2.

ASH1.1.1.1.

ASH1.2.1.2.

ASH2.1.2.1.

$\mathrm{ASH} 2.2 .2 .2$.

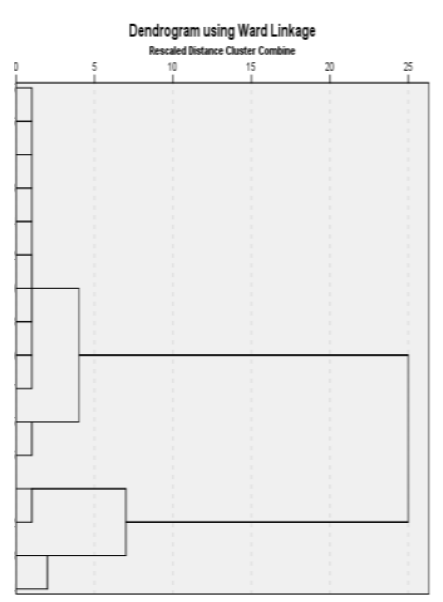

Şekil 3. ASH Madde Alt Boyut Kümelemesi

DM4.1.4.1.

DM4.2. $\overline{4.2 .}$

DM3.1. $\overline{3.1 .}$

DM3.2.3.2. 
DM2.1.2.1.

DM2.2.2.2.

İSH4.1.4.1.

İSH4.2.4.2.

İSH3.1.3.1.

İSH3.2.3.2.

İSH2.1.2.1.

İSH2.2.2.2.

İSH1.1.1.1.

İSH1.2.1.2.

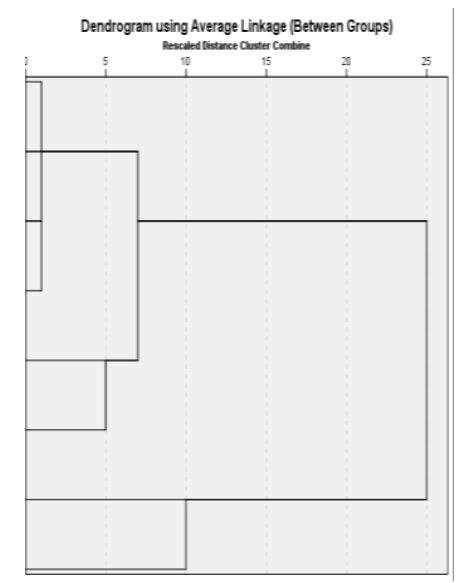

Şekil 4. İSH Madde Alt Boyut Kümelemesi
DM1.1.1.1.

DM1.2.1.2.

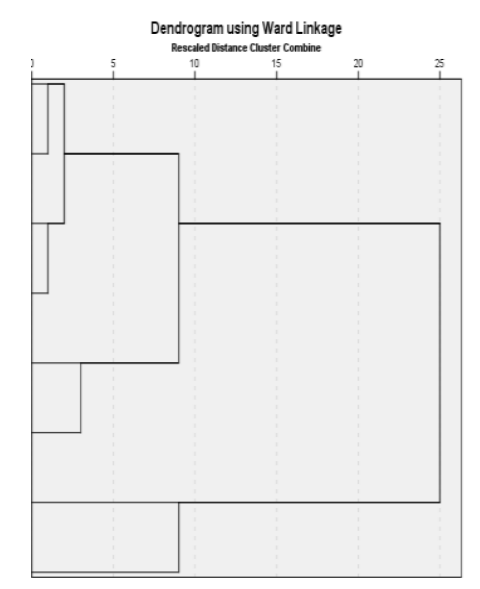

Şekil 5. DM Madde Alt Boyut Kümelemesi

Şekil 2'de görüldüğü gibi GRH alt ölçeğine ait maddeler, birinci alt boyutta 2 madde, ikinci alt boyutta 1 madde ve üçüncü alt boyutta 2 madde olmak üzere üç alt boyutta toparlanabilmektedir. 4 . ve 5 . maddeye ait denemeler (4.1., 4.2., 5.1. ve 5.2.) birinci alt boyutta, 3. maddeye ait denemeler (3.1. ve 3.2.) ikinci alt boyutta, 1. ve 2. maddeye ait denemeler (1.1., 1.2., 2.1.) üçüncü alt boyutta toplanmıştır. Şekil 3.'de ASH alt ölçeğine ait maddeler, birinci alt boyutta 3 madde, ikinci alt boyutta 2 madde olmak üzere iki alt boyutta toparlanabilmektedir. 3., 4. ve 5. maddeye ait denemeler (3.1., 3.2., 4.1., 4.2., 5.1. ve 5.2.) birinci alt boyutta toplanırken 1. ve 2. maddeye ait denemeler (1.1, 1.2., 2.1. ve 2.2.) ikinci alt boyutta toplanmıştır. Şekil 4.'de İSH alt ölçeğine ait maddeler, birinci alt boyutta 3 madde, ikinci alt boyutta 1 madde olmak üzere iki alt boyutta toparlanabilmektedir. 2., 3. ve 4. maddelere ait denemeler (2.1., 2.2., 3.1., 3.2., 4.1. ve 4.2.) birinci alt boyutta toplanırken 1. maddeye ait denemeler (1.1. ve 1.2.) ikinci alt boyutta toplanmıştır. Şekil 5.'de DM alt ölçeğine ait maddeler ise, birinci alt boyutta 3 madde, ikinci alt boyutta 1 madde olmak üzere iki alt boyutta toparlanabilmektedir. 2., 3. ve 4. maddelere ait denemeler (2.1., 2.2., 3.1., 3.2., 3.2., 4.2. ve 4.2.) birinci alt boyutta toplanırken 1. maddeye ait denemeler (1.1. ve 1.2.) ikinci alt boyutta toplanmıştır. Kümeleme analizi sonucunda GRH, ASH alt ölçekleri için üç alt boyut, İSH ve DM alt ölçekleri için iki alt boyut tanımlanmıştır. Kümelenme biçimleri incelendiğinde denemelerin ve maddelerin ardışık sırasının bozulmadığı görülmektedir. Maddeler sıralı olarak kümelenmiştir. Buna göre oluşan alt boyutların düşük-orta-yüksek ya da düşük-yüksek şeklinde tanımlanması mümkün görünmektedir. Kümeleme analizi sonucunda GRH ile DM alt ölçekleri için TBA ile benzer sonuçlar elde edilirken, ASH alt ölçeği için TBA'nde ihmal edilen 5. maddeye ait denemelerin (5.1 ve 5.2.) ve İSH alt ölçeği için TBA'nde ihmal edilen 4. maddeye ait denemelerin (4.1. ve 4.2.) bir grupta toplandığ gözlemlenerek ihmal edilmemesine karar verilmiştir (bkz. şekil 3 ve 4). Son aşamada GRH, ASH, İSH ve DM alt ölçekleri için sırasıyla 5, 4, 4, 4 toplam madde sayılarına ulaşılmış ve faktör analizi sonuçlarına yönelik yeterli kanıtlar sağlanabilmiştir.

\section{İkinci Deneme Uygulamasına İlişsin TBA Sonuçları}

Her bir alt ölçeğin ikinci deneme uygulamaları verilerinin öncelikle TBA'ne uygunluğu incelenmiştir. RH, SH, GRH, ASH, İSH, DM, BH, FOS ve MAE alt ölçeklerine ait deneme verilerinin KMO değerleri sırasıly .62, .74, .73, .60, 
$.66, .65, .83, .82, .79$ ve Bartlett testi sonuçları sırasılyla $X^{2}=2645.01,1055.40,2254.21,1200.21,1155.75,1722.97$, $2562.58,2736.83,2283.42,(\mathrm{df}=66,28,45,28,15,28,45,66,28, p<.05)$ temelinde TBA'ne uygun olduğu değerlendirilmiştir. Tüm alt ölçeklere ait TBA sonuçları Tablo 4'de verilmiştir.

Tablo 3. Çalışma Belleği Alt ölçekleri için İkinci Deneme Uygulaması TBA Sonuçları

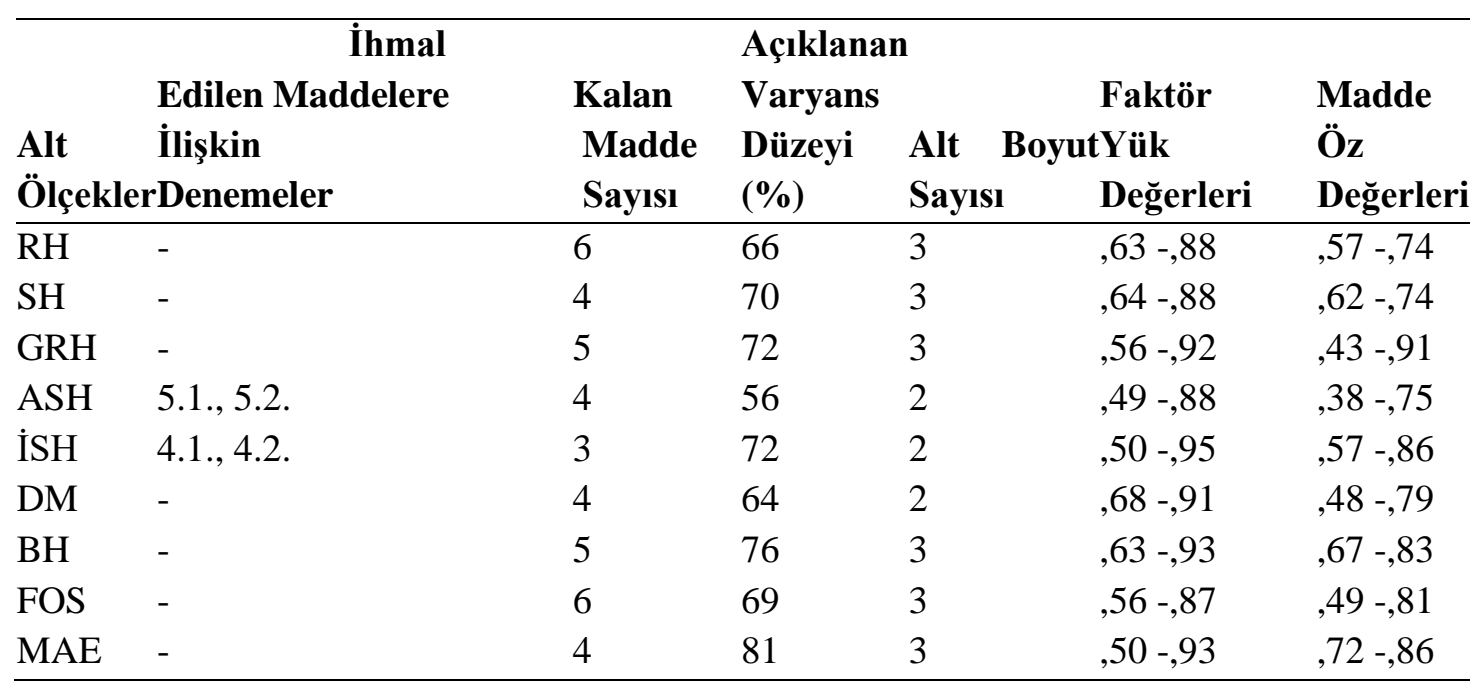

Tablo 3'de görüldüğü gibi faktör yük değerleri açısından binişik madde bulunmamış ve TBA çıktıları tüm alt ölçeklerin yapı geçerliğinin yüksek olduğunu göstermiştir. KMO değerlerinin düşük olması ve örneklemin sinırlılı̆̆ sebebiyle TBA sonuçlarını desteklemek üzere ASH ve İSH alt ölçekleri üzerinde yürütülen kümeleme analizi sonucu elde edilen dendogramlar Şekil 6 ve 7'de verilmiştir.

ASH5.1. 5.1.

ASH5.2. 5.2.

ASH4.1. 4.1.

ASH4.2. 4.2.

ASH3.1. 3.1.

ASH3.2. 3.2.

ASH1.1. 1.1.

ASH1.2. 1.2.

ASH2.1. 2.1.

ASH2.2. 2.2.

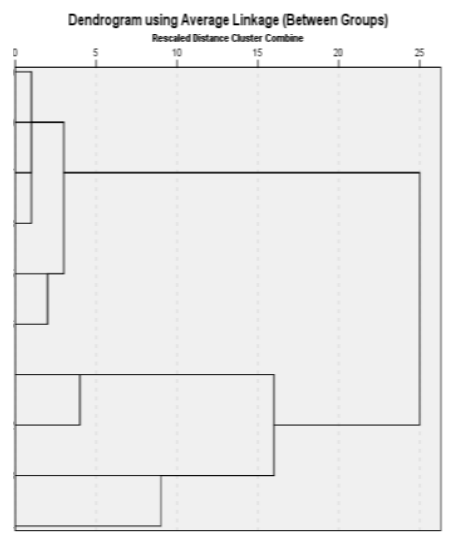

İSH4.1.4.1.

İSH4.2.4.2.

İSH3.1.3.1.

İSH3.2.3.2.

İSH2.1.2.1.

İSH2.2.2.2.

İSH1.1.1.1.

İSH1.2.1.2.

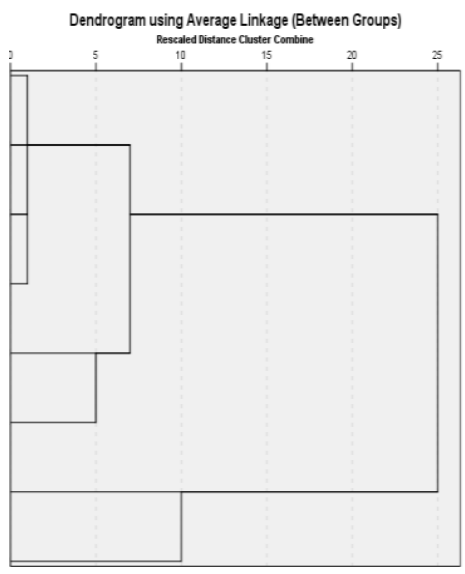

Şekil 6. ASH Madde Alt Boyut Kümelemesi Şekil 7. İSH Madde Alt Boyut Kümelemesi

Şekil 6.'da ASH alt ölçeğine ait maddeler, birinci alt boyutta 3 madde, ikinci alt boyutta 2 madde olmak üzere iki alt boyutta toparlanabilmektedir. 3., 4. ve 5. maddeye ait denemeler (3.1., 3.2., 4.1., 4.2., 5.1. ve 5.2.) birinci alt boyutta toplanırken 1. ve 2 . maddeye ait denemeler $(1.1,1.2 ., 2.1$. ve 2.2.) ikinci alt boyutta toplanmıştır. Şekil 7.' de 
İSH alt ölçeğine ait maddeler, birinci alt boyutta 3 madde, ikinci alt boyutta 1 madde olmak üzere iki alt boyutta toparlanabilmektedir. 2., 3. ve 4. maddelere ait denemeler (2.1., 2.2., 3.1., 3.2., 4.1. ve 4.2.) birinci alt boyutta toplanırken 1. maddeye ait denemeler (1.1. ve 1.2.) ikinci alt boyutta toplanmıştır. Kümeleme analizi sonucunda ASH ve İSH alt ölçeklerine ilişkin son aşamada ASH alt ölçeği için üç alt boyut, İSH alt ölçeği için iki alt boyut tanımlanmıştır. Kümelenme biçimleri incelendiğinde denemelerin ve maddelerin ardışık sırasının bozulmadığ 1 görülmektedir. Maddeler sıralı olarak kümelenmiştir. Buna göre oluşan alt boyutların düşük-orta-yüksek ya da düşükyüksek şeklinde tanımlanması mümkün görünmektedir. Kümeleme analizi sonucunda ASH alt ölçeği için TBA'nde ihmal edilen 5. maddeye ait denemelerin (5.1 ve 5.2.) ve İSH alt ölçeği için TBA'nde ihmal edilen 4. maddeye ait denemelerin (4.1. ve 4.2.) bir grupta toplandığı gözlemlenerek ihmal edilmemesine karar verilmiştir (bkz. Şekil 6 ve 7). Son aşamada ASH ve İSH alt ölçekleri için sırasıyla 5, 4 toplam madde sayılarına ulaşılmış ve faktör analizi sonuçlarına yönelik yeterli kanıtlar sağlanabilmiştir.

\section{Esas Uygulamaya İlişkin DFA Sonuçları}

ÇBÖ'nin uygulanması sonucunda alt boyutlara yönelik 4, bellek alanlarına yönelik 2 ve bir genel toplam olmak üzere 7 puan elde edilmesi, bu toplam puanlar üzerinden değerlendirme yapılması planlanmıştır. Buna göre 3 birincil düzey yapısal model tanımlanmış ve bu modeller üzerinde her sınıf düzeyine ilişkin "doğrulayıcı faktör analizi (DFA)" ile model-veri uyumları test edilmiştir. Sonuçlar Şekil 8'de verilmiştir.

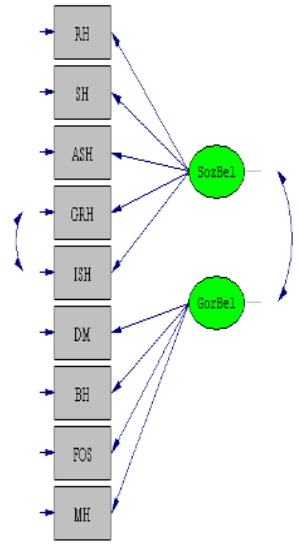

Anasinifi

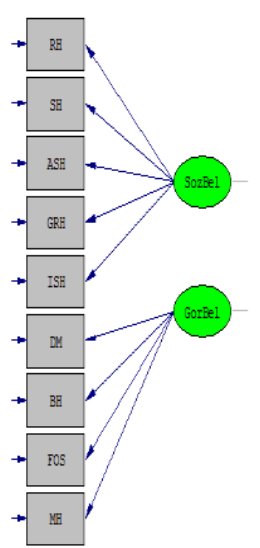

1. Sinıf

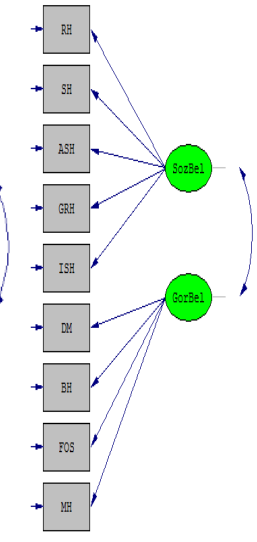

2. Sinif

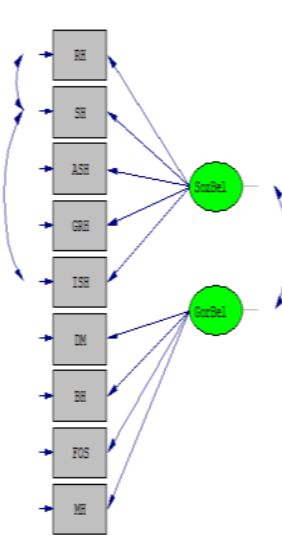

3. Sinıf

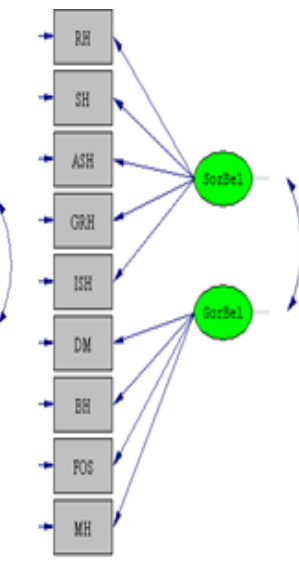

4. Sinif

Şekil 8. Doğrulayıcı faktör analizi (DFA) sonuçları

Şekil 8'de görüldüğü gibi ÇBÖ'ne ilişkin test edilen modeller birincil düzey bir yapısal modeldir ve 9 gözlenen değişken ile çalışma belleğini temsil eden birincil düzey gizil değişkenlerden oluşmaktadır. Her bir alt boyutta yürütülen temel bileşenler analizi sonuçlarına göre "tek boyutluluğun" sağlandığına yönelik yeterli kanıtın sağlanmış olmasına bağlı olarak, her bir alt boyut toplam puanları, sürekli gözlenen değişkenler olarak belirlenmiş ve analize dahil edilmiştir. Elde edilen uyum iyiliği değerleri Tablo 5'de verilmiştir.

Tablo 4'de görüldüğü gibi model veri uyumuna yönelik değeri $x^{2}$ manidardır ve $x^{2} /$ sd oranı 5 'in altındadır. Bu değer mükemmele yakın model-veri uyumuna işaret etmektedir. Hata terimlerine yönelik RMSEA ve RMR değerleri ,05 ile ,10 arasında olup değerler kabul edilebilir düzeyde model-veri uyumuna işaret etmektedir. Diğer uyum iyiliği indeksleri ise 90 'ın üzerindedir ve değerler mükemmele yakın model-veri uyumuna işaret etmektedir. Uyum iyiliğine yönelik tüm bu kestirimler birlikte değerlendirildiğinde ÇBÖ’nin yüksek düzeyde model-veri uyumunu sağladığını göstermektedir. Modele yönelik standartlaştırılmış yol katsayıları Şekil 9'da verilmiştir.

Şekil 9'da görüldüğü gibi modelde yer alan tüm alt boyutlar ile çalışma belleği arasında pozitif yönlü korelasyonlar bulunmaktadır. Anasınıfı düzeyinde sözel belleğin en iyi yordayıcısının SH ve görsel belleğin en iyi yordayıcısının BH olduğu, 1. sınıf, 2. sınıf ve 4. sınıf düzeylerinde sözel belleğin en iyi yordayıcısının SH, görsel belleğin en iyi yordayıcısının FOS olduğu, 3. sınıf düzeyinde sözel belleğin en iyi yordayıcısının ISH ve görsel belleğin en iyi yordayıcısının BH olduğu görülmektedir.

Tablo 4. ÇBÖ Model-Veri Uyum İyiliği Değerleri 


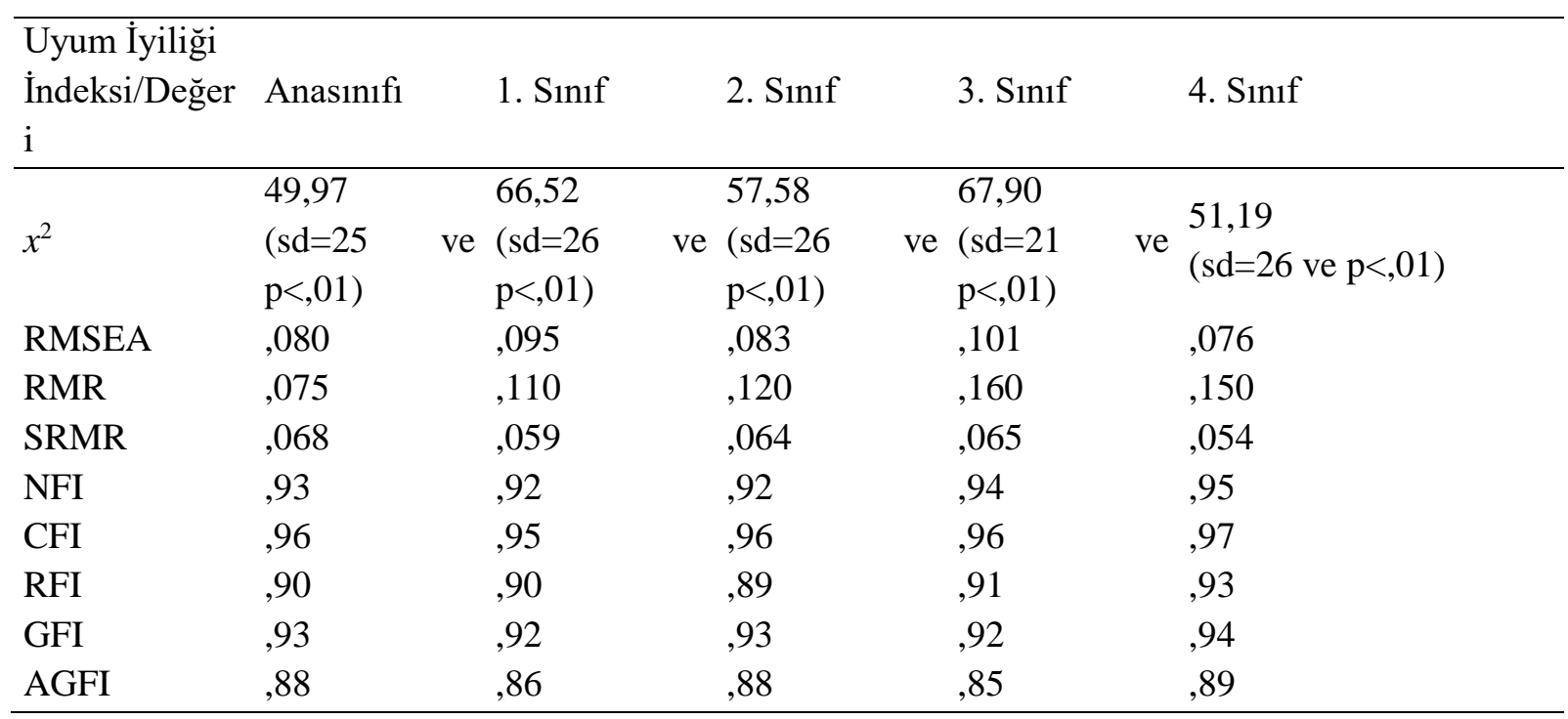

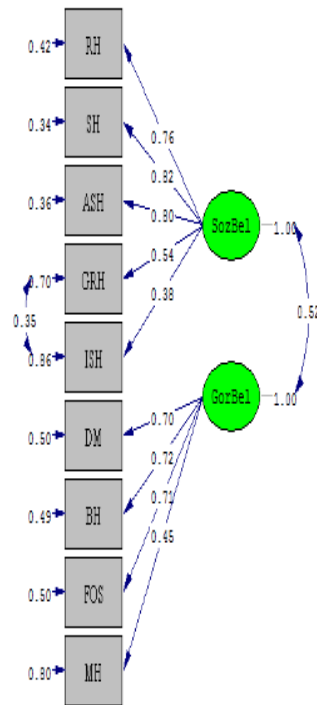

Anasinifi

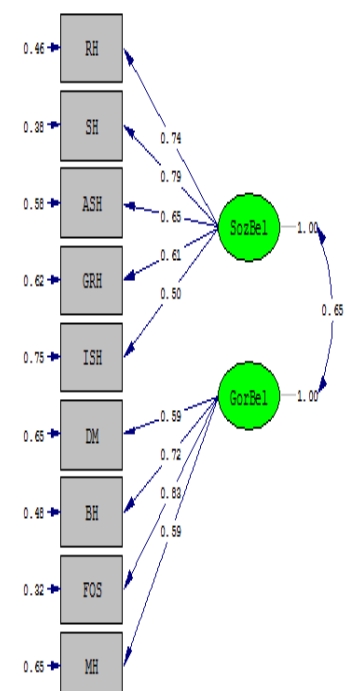

1. Sinif

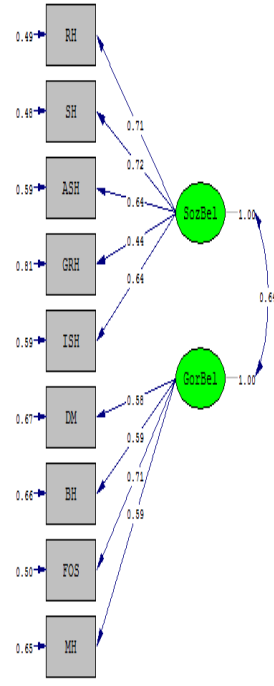

2. Sinif

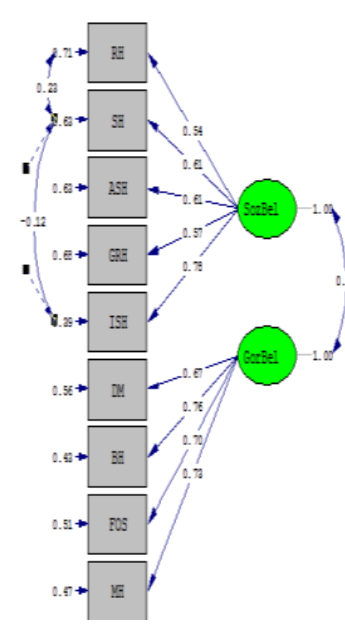

3. Sinif

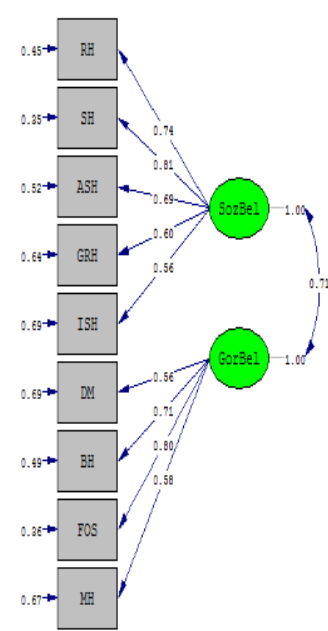

4. Sinif

Şekil 4. ÇBÖ Modeli Standartlaştırılmış Yol Katsayıları.

Genel değerlendirme sonucunda, TBA'ni desteklemek amaciyla birinci deneme uygulaması verileri üzerinde GRH, ASH, İSH ve DM alt ölçekleri için, ikinci deneme uygulaması verileri üzerinde ASH ve İSH alt ölçekleri için kümeleme analizi de yürütülerek gerekli iyileştirmeler sağlanmıştır. Açımlayıcı ve doğrulayıcı çalışmalar sonucunda ÇBÖ’nin alt ölçek, madde ve deneme sayıları yüksek yapı geçerliği sağlanacak biçimde düzenlenmiştir. Sonuç olarak ÇBÖ’ne ilişkin yapı geçerliği çalışmaları sonucunda deneme uygulaması verileri üzerinde yürütülen TBA ile açımlanmış, esas uygulama verileri üzerinde yürütülen DFA ile doğrulanmıştır.

\section{ÇBÖ’nin Ayırıcılık Çalışmaları}

Yap1 geçerliği çalışmalarından sonra her alt ölçek için deneme-toplam puan korelasyonları üzerinden ayırıcılık anlamında geçerlik çalışmaları yapılmıştır. Birinci, ikinci deneme ve esas uygulama verileri üzerinde yürütülen madde ayırıcılığı çalışmaları sonucunda alt ölçeklere ilişkin deneme toplam puan korelasyonları "nokta-çift serili korelasyon katsayısı" ile hesaplanmıştır. Birinci deneme uygulamasına ilişkin alt ölçeklerin deneme toplam puan korelasyonlarına ilişkin bilgiler Tablo 6'da sunulmaktadır.

Tablo 5'de görüldügü gibi deneme-toplam puan korelasyonları tüm alt ölçekler için madde ayırıcılıkları hesaplanamayan maddeler hariç 0,01 düzeyinde manidardır ve ortalama ayırıcılıkları orta ve yüksek düzeydedir. Bununla birlikte RH alt ölçeğinin 5. maddesine ait 5.2. denemesi ile SH alt ölçeğinin 1. maddesine ait 1.1. ve 1.2. denemeleri ,20-,29 arasında sınırda, RH alt ölçeğinin 6. maddesine ait 6.1. ve 6.2. denemeleri, GRH alt ölçeğinin 5. maddesine ait 5.2. denemesi ile FOS alt ölçeğinin 6. maddesine ait 6.1. ve 6.2. denemelerinin ise ayırıc1lıkları düşüktür. Ayrıca varyansın oluşmaması sebebiyle ASH alt ölçeğinin 5. maddesine ait denemeler ile İSH alt ölçeğinin 
4. maddesine ait denemelerin ayırıcılıkları hesaplanamamıştır. Buna karşın, bu maddelerin yüksek beceri örüntülerini ölçtüğü ve bu becerilere ulaşabilecek çocuk sayısının az olduğu düşünülerek, ayrıca kümeleme analizinin sonuçları dikkate alınarak testte kalmalarına karar verilmiştir. Alt ölçekler düzeyinde diğer maddelerin madde ayırıcıklıklarının ,32 ile ,82 arasında değiştiği görülmektedir. Bu değerler ölçeğin ayırıcılık anlamında geçerlik düzeyinin de yüksek olduğunu göstermektedir. İkinci deneme uygulamasına ilişkin alt ölçeklerin deneme toplam puan korelasyonlarına ilişkin bilgiler Tablo 6'da sunulmaktadır.

Tablo 5. Birinci Deneme Uygulamasına İlişkin Alt Ölçeklerin Deneme-Toplam Puan Korelasyonları

\begin{tabular}{|c|c|c|}
\hline \multicolumn{3}{|c|}{$\overline{\text { Sözel Alt Ölçekler }}$} \\
\hline Madde & Deneme & $\mathbf{r}_{\text {pbis }}$ \\
\hline \multirow{2}{*}{ RH1 } & RH1.1. & ,60 \\
\hline & RH1.2. & ,64 \\
\hline \multirow{2}{*}{ RH2 } & RH2.1. &, 78 \\
\hline & RH2.2. &, 79 \\
\hline \multirow{2}{*}{ RH3 } & RH3.1. &, 75 \\
\hline & RH3.2. & ,73 \\
\hline \multirow{2}{*}{ RH4 } & RH4.1. &, 54 \\
\hline & RH4.2. & 45 \\
\hline \multirow{2}{*}{ RH5 } & RH5.1. &, 32 \\
\hline & RH5.2. &, 27 \\
\hline \multirow{2}{*}{ RH6 } & RH6.1. &, 19 \\
\hline & RH6.2. &, 10 \\
\hline \multirow{2}{*}{ SH1 } & SH1.1. & 22 \\
\hline & SH1.2. &, 27 \\
\hline \multirow{2}{*}{$\mathrm{SH} 2$} & SH2.1. & ,65 \\
\hline & SH2.2. &, 74 \\
\hline \multirow{2}{*}{ SH3 } & SH3.1. &, 81 \\
\hline & SH3.2. &, 80 \\
\hline \multirow{2}{*}{ SH4 } & SH4.1. &, 59 \\
\hline & SH4.1. &, 59 \\
\hline \multirow{2}{*}{ GRH1 } & GRH1.1. & ,68 \\
\hline & GRH1.2. & ,69 \\
\hline \multirow{2}{*}{ GRH2 } & GRH2.1. &, 78 \\
\hline & GRH2.2. & ,79 \\
\hline \multirow{2}{*}{ GRH3 } & GRH3.1. & ,65 \\
\hline & GRH3.2. &, 67 \\
\hline \multirow{2}{*}{ GRH4 } & GRH4.1. &, 46 \\
\hline & GRH4.2. &, 47 \\
\hline \multirow{2}{*}{ GRH5 } & GRH5.1. &, 38 \\
\hline & GRH5.2. &, 21 \\
\hline \multirow{2}{*}{ ASH1 } & ASH1.1. &, 44 \\
\hline & ASH1.2. &, 57 \\
\hline \multirow{2}{*}{ ASH2 } & ASH2.1. &, 77 \\
\hline & ASH2.2. &, 77 \\
\hline \multirow{2}{*}{ ASH3 } & ASH3.1. &, 58 \\
\hline & ASH3.2. & ,61 \\
\hline \multirow{2}{*}{ ASH4 } & ASH4.1. &, 40 \\
\hline & ASH4.2. &, 36 \\
\hline \multirow{2}{*}{ ASH5* } & ASH5.1. & - \\
\hline & ASH5.2. & - \\
\hline \multirow{2}{*}{ İSH1 } & İSH1.1. & ,76 \\
\hline & İSH1.2. &, 77 \\
\hline \multirow{2}{*}{ İSH2 } & İSH2.1. &, 69 \\
\hline & İSH2.2. & ,69 \\
\hline & İSH3.1. &, 54 \\
\hline ISH3 & İSH3.2. & 49 \\
\hline & İSH4.1. & - \\
\hline ISH4 & İSH4.2. & - \\
\hline
\end{tabular}

\begin{tabular}{|c|c|c|}
\hline \multicolumn{3}{|c|}{ Görsel Alt Ölçekler } \\
\hline Madde & Deneme & $\mathbf{r}_{\mathrm{pbis}}$ \\
\hline \multirow{2}{*}{ DM1 } & DM1.1. & ,63 \\
\hline & DM1.2. &, 71 \\
\hline \multirow{2}{*}{ DM2 } & DM2.1. &, 76 \\
\hline & DM2.2. &, 75 \\
\hline \multirow{2}{*}{ DM3 } & DM3.1. & ,64 \\
\hline & DM3.2. & ,60 \\
\hline \multirow{2}{*}{ DM4 } & DM4.1. & ,46 \\
\hline & DM4.2. & ,47 \\
\hline \multirow{2}{*}{ BH1 } & BH1.1. & ,65 \\
\hline & BH1.2. & ,68 \\
\hline \multirow{2}{*}{ BH2 } & BH2.1. &, 75 \\
\hline & BH2.2. &, 70 \\
\hline \multirow{2}{*}{$\mathrm{BH} 3$} & BH3.1. &, 70 \\
\hline & BH3.2. &, 75 \\
\hline \multirow{2}{*}{ BH4 } & BH4.1. & ,62 \\
\hline & BH4.2. & ,60 \\
\hline \multirow{2}{*}{ BH5 } & BH5.1. & ,47 \\
\hline & BH5.2. & ,42 \\
\hline \multirow{2}{*}{ FOS1 } & FOS1.1. & ,64 \\
\hline & FOS1.2. & ,68 \\
\hline \multirow{2}{*}{ FOS2 } & FOS2.1. & 80 \\
\hline & FOS 2.2 &, 82 \\
\hline \multirow{2}{*}{ FOS3 } & FOS3.1. &, 78 \\
\hline & FOS3.2. &, 81 \\
\hline \multirow{2}{*}{ FOS4 } & FOS4.1. & ,69 \\
\hline & FOS4.2. & ,61 \\
\hline \multirow{2}{*}{ FOS5 } & FOS5.1. &, 57 \\
\hline & FOS5.2. &, 51 \\
\hline \multirow{2}{*}{ FOS6 } & FOS6.1. &, 27 \\
\hline & FOS6.2. &, 21 \\
\hline \multirow{2}{*}{ MAE1 } & MAE1.1. & ,70 \\
\hline & MAE1.2. &, 73 \\
\hline \multirow{2}{*}{ MAE2 } & MAE2.1. &, 81 \\
\hline & MAE2.2. &, 79 \\
\hline \multirow{2}{*}{ MAE3 } & MAE3.1. &, 71 \\
\hline & MAE3.2. &, 70 \\
\hline \multirow[t]{2}{*}{ MAE4 } & MAE4.1. &, 56 \\
\hline & MAE4.2. & 46 \\
\hline
\end{tabular}

Tablo 6. İkinci Deneme Uygulamasına İlişkin Alt Ölçeklerin Deneme-Toplam Puan Korelasyonları

\begin{tabular}{lll}
\hline \multicolumn{2}{l}{ Sözel Alt Ölçekler } \\
\hline Madde & Deneme & $\mathbf{r}_{\text {pbis }}$ \\
\hline RH1 & RH1.1. &, 52 \\
& RH1.2. &, 58
\end{tabular}

\begin{tabular}{lll}
\hline \multicolumn{2}{l}{ Görsel Alt Ölçekler } & \\
\hline Madde & Deneme & $\mathbf{r}_{\text {pbis }}$ \\
\hline DM1 & DM1.1. &, 66 \\
& DM1.2. &, 72
\end{tabular}




\begin{tabular}{|c|c|c|c|c|c|}
\hline \multirow{2}{*}{ RH2 } & RH2.1. &, 74 & \multirow{2}{*}{$\mathrm{DM} 2$} & DM2.1. & ,74 \\
\hline & RH2.2. &, 73 & & DM2.2. &, 74 \\
\hline \multirow{2}{*}{ RH3 } & RH3.1. &, 77 & \multirow{2}{*}{ DM3 } & DM3.1. &, 59 \\
\hline & RH3.2. &, 73 & & DM3.2. &, 55 \\
\hline \multirow{2}{*}{ RH4 } & RH4.1. &, 56 & \multirow{2}{*}{ DM4 } & DM4.1. & ,40 \\
\hline & RH4.2. & ,49 & & DM4.2. & ,40 \\
\hline \multirow{2}{*}{ RH5 } & RH5.1. & ,29 & \multirow{2}{*}{ BH1 } & BH1.1. & ,61 \\
\hline & RH5.2. & ,23 & & BH1.2. & ,69 \\
\hline \multirow{2}{*}{ RH6 } & RH6.1. & ,13 & \multirow{2}{*}{$\mathrm{BH} 2$} & BH2.1. & ,78 \\
\hline & RH6.2. &, 07 & & BH2.2. & ,78 \\
\hline \multirow{2}{*}{ SH1 } & SH1.1. &, 32 & \multirow{2}{*}{ BH3 } & BH3.1. & ,78 \\
\hline & SH1.2. &, 32 & & BH3.2. & ,79 \\
\hline \multirow{2}{*}{$\mathrm{SH} 2$} & SH2.1. & ,67 & \multirow{2}{*}{$\mathrm{BH} 4$} & BH4.1. & ,69 \\
\hline & SH2.2. &, 73 & & BH4.2. & ,61 \\
\hline \multirow{2}{*}{ SH3 } & SH3.1. & ,82 & \multirow{2}{*}{ BH5 } & BH5.1. & ,48 \\
\hline & SH3.2. &, 79 & & BH5.2. & ,42 \\
\hline \multirow{2}{*}{ SH4 } & SH4.1. & ,48 & \multirow{2}{*}{ FOS1 } & FOS1.1. & ,56 \\
\hline & SH4.1. &, 56 & & FOS1.2. & ,67 \\
\hline \multirow{2}{*}{ GRH1 } & GRH1.1. & ,63 & \multirow{2}{*}{ FOS2 } & FOS2.1. & ,76 \\
\hline & GRH1.2. & ,68 & & FOS2.2. & ,79 \\
\hline \multirow{2}{*}{ GRH2 } & GRH2.1. & ,78 & \multirow{2}{*}{ FOS3 } & FOS3.1. & ,76 \\
\hline & GRH2.2. &, 78 & & FOS3.2. & ,78 \\
\hline \multirow{2}{*}{ GRH3 } & GRH3.1. & ,66 & & FOS4.1. & ,65 \\
\hline & GRH3.2. & ,65 & FOS4 & FOS4.2. &, 58 \\
\hline & GRH4.1. & ,49 & & FOS5.1. &, 53 \\
\hline GRH4 & GRH4.2. & ,48 & FUSS & FOS5.2. & ,46 \\
\hline GRH 5 & GRH5.1. &, 42 & FOS6 & FOS6.1. & ,20 \\
\hline GRHS & GRH5.2. &, 22 & FUso & FOS6.2. &, 15 \\
\hline & ASH1.1. & 47 & $M \wedge F 1$ & MAE1.1. & ,64 \\
\hline ASHI & ASH1.2. &, 51 & MAEI & MAE1.2. &, 72 \\
\hline$\triangle \mathrm{SH}$ & ASH2.1. &, 77 & MAE? & MAE2.1. & ,78 \\
\hline ASH 2 & ASH2.2. &, 77 & MAE2 & MAE2.2. & ,79 \\
\hline$\triangle \mathrm{SH}$ & ASH3.1. & ,59 & $\mathrm{MAF3}$ & MAE3.1. &, 73 \\
\hline ASH3 & ASH3.2. &, 57 & MAE3 & MAE3.2. &, 72 \\
\hline$\triangle \mathrm{SH}$ & ASH4.1. &, 35 & MAE4 & MAE4.1. & ,61 \\
\hline ASH4 & ASH4.2. & ,32 & & MAE4.2. & ,48 \\
\hline ASH5 & ASH5.1. & - & & & \\
\hline ASHD & ASH5.2. & - & & & \\
\hline & İSH1.1. & ,69 & & & \\
\hline ISHI & İSH1.2. &, 80 & & & \\
\hline & İSH2.1. & ,71 & & & \\
\hline ISH2 & İSH2.2. & ,69 & & & \\
\hline İSH3 & İSH3.1. & ,47 & & & \\
\hline ISH3 & İSH3.2. & ,48 & & & \\
\hline İCH4 & İSH4.1. & - & & & \\
\hline ISH4 & İSH4.2. & - & & & \\
\hline
\end{tabular}

Tablo 6'da görüldüğü gibi deneme-toplam puan korelasyonları tüm alt ölçekler için madde ayırıcılıkları hesaplanamayan maddeler hariç 0,01 düzeyinde manidardır ve ortalama ayırıcılıkları orta ve yüksek düzeydedir. RH alt ölçeğinin 5. maddesine ait 5.1. ve 5.2. denemeleri ile GRH alt ölçeğinin 5. maddesine ait 5.2. denemesi ,20-,29 arasında sınırda, RH alt ölçeğinin 6. maddesine ait 6.1. ve 6.2. denemeleri ile FOS alt ölçeğinin 6. maddesine ait 6.1. ve 6.2. denemelerinin ise ayırıcılıkları düşüktür. Ayrıca varyansın oluşmaması sebebiyle ASH alt ölçeğinin 5 . maddesine ait denemeler ile İSH alt ölçeğinin 4. maddesine ait denemelerin ayırıcılıkları hesaplanamamıştır. Buna karşın, bu maddelerin yüksek beceri örüntülerini ölçtüğü ve bu becerilere ulaşabilecek çocuk sayısının az olduğu düşünülerek, ayrıca kümeleme analizinin sonuçları dikkate alınarak testte kalmalarına karar verilmiştir. Alt ölçekler düzeyinde diğer maddelerin madde ayırıcılıklarının ,32 ile ,82 arasında değiştiği görülmektedir. Bu değerler ölçeğin ayırıcılık anlamında geçerlik düzeyinin de yüksek olduğunu göstermektedir. Esas uygulamaya ilişkin alt ölçeklerin deneme toplam puan korelasyonlarına ilişkin bilgiler Tablo 7'de sunulmaktadır. 
Tablo 7. Esas Uygulamaya İlişkin Alt Ölçeklerin Madde-Toplam Puan Korelasyonları

\begin{tabular}{|c|c|c|}
\hline \multicolumn{3}{|c|}{ Sözel Alt Ölçekler } \\
\hline Madde & Deneme & $\mathbf{r}_{\text {pbis }}$ \\
\hline \multirow{2}{*}{ RH1 } & RH1.1. & ,16 \\
\hline & RH1.2. & ,31 \\
\hline \multirow{2}{*}{ RH2 } & RH2.1. & ,63 \\
\hline & RH2.2. &, 53 \\
\hline \multirow{2}{*}{ RH3 } & RH3.1. &, 75 \\
\hline & RH3.2. &, 75 \\
\hline \multirow{2}{*}{ RH4 } & RH4.1. & ,65 \\
\hline & RH4.2. & ,63 \\
\hline \multirow{2}{*}{ RH5 } & RH5.1. &, 48 \\
\hline & RH5.2. &, 41 \\
\hline \multirow{2}{*}{ RH6 } & RH6.1. &, 22 \\
\hline & RH6.2. & ,18 \\
\hline \multirow{2}{*}{ SH1 } & SH1.1. & 36 \\
\hline & SH1.2. &, 38 \\
\hline \multirow{2}{*}{$\mathrm{SH} 2$} & SH2.1. & ,68 \\
\hline & SH2.2. & ,68 \\
\hline \multirow{2}{*}{ SH3 } & SH3.1. & ,66 \\
\hline & SH3.2. & ,69 \\
\hline \multirow{2}{*}{ SH4 } & SH4.1. &, 51 \\
\hline & SH4.1. &, 41 \\
\hline \multirow{2}{*}{ GRH1 } & GRH1.1. & 62 \\
\hline & GRH1.2. & ,62 \\
\hline \multirow{2}{*}{ GRH2 } & GRH2.1. &, 73 \\
\hline & GRH2.2. &, 72 \\
\hline \multirow{2}{*}{ GRH3 } & GRH3.1. & ,68 \\
\hline & GRH3.2. & ,68 \\
\hline \multirow{2}{*}{ GRH4 } & GRH4.1. &, 46 \\
\hline & GRH4.2. &, 40 \\
\hline \multirow{2}{*}{ GRH5 } & GRH5.1. &, 10 \\
\hline & GRH5.2. &, 19 \\
\hline \multirow{2}{*}{ ASH1 } & ASH1.1. & ,33 \\
\hline & ASH1.2. &, 35 \\
\hline \multirow{2}{*}{ ASH2 } & ASH2.1. &, 71 \\
\hline & ASH2.2. &, 75 \\
\hline \multirow{2}{*}{ ASH3 } & ASH3.1. & ,61 \\
\hline & ASH3.2. & ,64 \\
\hline \multirow{2}{*}{ ASH4 } & ASH4.1. &, 33 \\
\hline & ASH4.2. &, 38 \\
\hline \multirow{2}{*}{ ASH5 } & ASH5.1. &, 11 \\
\hline & ASH5.2. & - \\
\hline \multirow{2}{*}{ İSH1 } & İSH1.1. & ,71 \\
\hline & İSH1.2. & ,68 \\
\hline \multirow{2}{*}{ İSH2 } & İSH2.1. & ,63 \\
\hline & İSH2.2. &, 71 \\
\hline İSH3 & İSH3.1. &, 43 \\
\hline (1DS1) & İSH3.2. & ,29 \\
\hline İSH4 & İSH4.1. &, 14 \\
\hline ISH4 & İSH4.2. &, 03 \\
\hline
\end{tabular}

\begin{tabular}{|c|c|c|}
\hline \multicolumn{3}{|c|}{ Görsel Alt Ölçekler } \\
\hline Madde & Deneme & $\mathbf{r}_{\text {pbis }}$ \\
\hline \multirow{2}{*}{ DM1 } & DM1.1. & 64 \\
\hline & DM1.2. & ,68 \\
\hline \multirow{2}{*}{ DM2 } & DM2.1. &, 72 \\
\hline & DM2.2. & ,68 \\
\hline \multirow{2}{*}{ DM3 } & DM3.1. & ,61 \\
\hline & DM3.2. & ,61 \\
\hline \multirow{2}{*}{ DM4 } & DM4.1. &, 34 \\
\hline & DM4.2. &, 47 \\
\hline \multirow{2}{*}{ BH1 } & BH1.1. & ,66 \\
\hline & BH1.2. & ,63 \\
\hline \multirow{2}{*}{$\mathrm{BH} 2$} & BH2.1. & ,64 \\
\hline & BH2.2. & ,71 \\
\hline \multirow{2}{*}{$\mathrm{BH} 3$} & BH3.1. &, 53 \\
\hline & BH3.2. &, 53 \\
\hline \multirow{2}{*}{ BH4 } & BH4.1. &, 28 \\
\hline & BH4.2. &, 29 \\
\hline \multirow{2}{*}{ BH5 } & BH5.1. & - \\
\hline & BH5.2. & - \\
\hline \multirow{2}{*}{ FOS1 } & FOS1.1. & ,54 \\
\hline & FOS1.2. &, 59 \\
\hline \multirow{2}{*}{ FOS2 } & FOS2.1. &, 71 \\
\hline & FOS2.2. &, 72 \\
\hline \multirow{2}{*}{ FOS3 } & FOS3.1. &, 70 \\
\hline & FOS3.2. &, 71 \\
\hline \multirow{2}{*}{ FOS4 } & FOS4.1. & 67 \\
\hline & FOS4.2. & ,60 \\
\hline \multirow{2}{*}{ FOS5 } & FOS5.1. &, 39 \\
\hline & FOS5.2. & ,41 \\
\hline \multirow{2}{*}{ FOS6 } & FOS6.1. & ,20 \\
\hline & FOS6.2. &, 11 \\
\hline \multirow{2}{*}{ MAE1 } & MAE1.1. & ,72 \\
\hline & MAE1.2. & 69 \\
\hline \multirow{2}{*}{ MAE2 } & MAE2.1. & ,63 \\
\hline & MAE2.2. & 65 \\
\hline \multirow{2}{*}{ MAE3 } & MAE3.1. &, 42 \\
\hline & MAE3.2. &, 36 \\
\hline \multirow[t]{2}{*}{ MAE4 } & MAE4.1. &, 12 \\
\hline & MAE4.2. & - \\
\hline
\end{tabular}

Tablo 7'de görüldüğ̈̈ gibi, deneme-toplam puan korelasyonları tüm alt ölçekler için madde ayırıcılıkları hesaplanamayan maddeler hariç 0,01 düzeyinde manidardır ve ortalama ayırıcılıkları orta ve yüksek düzeydedir. $\mathrm{RH}$ alt ölçeğinin 6. maddesine ait 6.1. denemesi, İSH alt ölçeğinin 3. maddesine ait 3.2. denemesi, BH alt ölçeğinin 4. maddesine ait 4.1. ve 4.2. denemeleri, FOS alt ölçeğinin 6. maddesine ait 6.1. denemesi ,20- ,29 arasında sinırda, RH alt ölçeğinin 1. maddesine ait 1.1. denemesi ile 6. maddesine ait 6.2. denemesi, GRH alt ölçeğinin 5. maddesine ait 5.1. ve 5.2. denemeleri, ASH alt ölçeğinin 5. maddesine ait 5.1. denemesi, İSH alt ölçeğinin 4. maddesine ait 4.1. ve 4.2. denemeleri, FOS alt ölçeğinin 6. maddesine ait 6.2. denemesi ile MAE alt ölçeğinin 4. maddesine ait 4.2. denemesinin ayırıcılıkları düşüktür. Ayrıca varyansın oluşmaması sebebiyle ASH alt ölçeğinin 5. maddesine ait 5.2. 
denemesi, BH alt ölçeğinin 5. maddesine ait 5.1. ve 5.2. denemeleri ile MAE alt ölçeğinin 4. maddesine ait 4.2. denemesinin madde ayırıcılıkları hesaplanamamıştır. Buna karşın, bu maddelerin yüksek beceri örüntülerini ölçtüğü ve bu becerilere ulaşabilecek çocuk sayısının az olduğu düşünülerek, ayrıca kümeleme analizinin sonuçları dikkate alınarak testte kalmalarına karar verilmiştir. Alt ölçekler düzeyinde diğer maddelerin ise madde ayırıcılıklarının ,31 ile ,75 arasında değiştiği görülmektedir. Bu değerler ölçeğin ayırıcılık anlamında geçerlik düzeyinin de yüksek olduğunu göstermektedir.

Genel değerlendirme. Madde düzeyinde ayırıcılıklarına bakıldığında her bir alt ölçekteki maddelerin çoğunluğunun yüksek ayırıcılıkta olduğu, alt ölçekler düzeyinde bakıldığında da test ayırıcılıklarının .30'un üzerinde yüksek olduğu görülmektedir (Turgut \& Baykul, 2010).

\section{ÇBÖ' ne İlişkin Ölçüt Geçerliği Sonuçları}

ÇBÖ’ne yönelik ölçüt geçerliği çalışmalarında anasınıfı, birinci ve ikinci sınıf ile üçüncü ve dördüncü sınıf çocuklarına yönelik olarak geliştirilen akademik başarı ölçeklerinden elde edilen puanlar ölçüt puanlar takımı olarak kullanılmıştır. Çalışma belleği alt ölçeği toplam puanları ile her sınıf düzeyine ait Akademik Başarı Ölçeği toplam puan korelasyonları "nokta-çift serili korelasyon katsayısı" ile hesaplanmış ve Tablo 8'de verilmiştir.

Tablo 8. ÇBÖ Alt Ölçekleri ile Akademik Başarı Ölçeği Arasındaki Madde-Toplam Puan Korelasyonları

\begin{tabular}{|c|c|c|c|c|}
\hline $\begin{array}{l}\text { Alt } \\
\text { Ölçekler }\end{array}$ & $\begin{array}{l}\text { Anasinıfi } \\
(\mathrm{N}=84)\end{array}$ & $\begin{array}{l}1 \\
(\mathrm{~N}=78)\end{array}$ & $\begin{array}{l}2 \\
(\mathrm{~N}=86)\end{array}$ & $\begin{array}{l}3-4 \\
(N=172)\end{array}$ \\
\hline$\overline{\mathrm{RH}}$ & $45^{* *}$ &, $54 * *$ & $45^{* *}$ & $45^{* *}$ \\
\hline GRH &, $43^{* *}$ &, $54 * *$ &, $44 * *$ &, $60^{* *}$ \\
\hline $\mathrm{SH}$ &, $45^{* *}$ &, $33^{* *}$ &, $38 * *$ &, $53 * *$ \\
\hline ASH &, $52 * *$ &, $44 * *$ &, $37 * *$ &, $44 * *$ \\
\hline İSH &, $23^{*}$ &, $31 * *$ &, $40 * *$ &, $45^{* *}$ \\
\hline DM &, $23^{*}$ &, $42 * *$ &, $32 * *$ &, $35^{* *}$ \\
\hline $\mathrm{BH}$ &, $27 *$ &, $58 * *$ &, $31 * *$ &, $39^{* *}$ \\
\hline FOS &, $30 * *$ &, $35 * *$ &, $34 * *$ &, $51^{* *}$ \\
\hline MAE &, 21 &, $46^{* *}$ &, $35 * *$ &, $45^{* *}$ \\
\hline
\end{tabular}

Tablo 8'de ÇBÖ ve başarı puanları arasında düşük ve orta korelasyonlar görülmektedir ve manidardır. Akademik başarı ile çalışma belleği farklı özellikler olmakla birlikte birbirleriyle ilişkili özelliklerdir (Gathercole \& Pickering, 2000). Dolayısıyla bunlar arasında çok yüksek korelasyonlar olması beklenmez (Urbina, 2004). Buna göre bu özellikler arasındaki orta düzey korelasyonların yüksek düzeyde ölçüt temelli geçerlik kanıtı sağladığı değerlendirilmiştir. Bununla birlikte MAE alt ölçeği ile anasınıfı Akademik Başarı Ölçeği arasındaki korelasyon manidar bulunmamıştır.

\section{ÇBÖ’ne İlişkin Güvenirlik Çalışmaları}

Güvenirlik çalışmaları olarak birinci, ikinci deneme ve esas uygulama verileri üzerinde test yarılama yöntemine dayalı iç tutarlık anlamında Cronbach Alpha iç tutarlık katsayısı ile ikinci deneme uygulaması verileri üzerinde test-tekrartest güvenirliği için Pearson Momentler Çarpımı Korelasyon Katsayısı hesaplanmıştır.

\section{Test Yarılama Yöntemine Dayalı Güvenirlik Sonuçları}

Bu kapsamda ÇBÖ’ne ait her bir alt ölçek için iç tutarlık anlamında Cronbach Alpha iç tutarlık katsayısı hesaplanmış ve sonuçlar Tablo 19'da verilmiştir.

Tablo 9'a göre ÇBÖ’ne ilişkin birinci, ikinci deneme uygulama verileri ve esas uygulama verileri üzerinde tüm alt ölçekler için Cronbach Alpha katsayısı hesaplanmış ve bu değerlerin birinci deneme uygulaması için ,69 ile ,85 arasında, ikinci deneme uygulaması için ,66 ile ,84 arasında ve esas uygulama için ,68 ile ,99 arasında değiştiği görülmüştür. $\mathrm{Bu}$ değerler ÇBÖ'nin iç tutarlılık anlamında güvenirlik düzeyinin orta ve yüksek olduğunu göstermektedir.

Tablo 9. ÇBÖ Alt Ölçeklerinin İç Tutarlılık Katsayıları

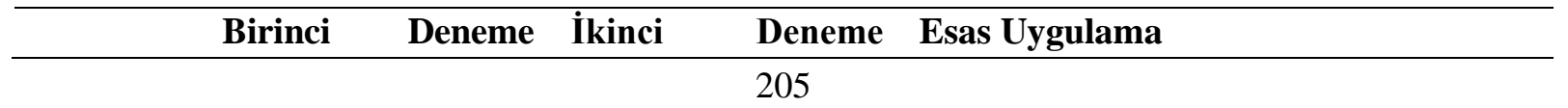




\begin{tabular}{llll}
\hline & $\begin{array}{l}\text { Uygulaması } \\
(\mathbf{N = 2 1 0})\end{array}$ & $\begin{array}{l}\text { Uygulaması } \\
(\mathbf{N = 4 2 4})\end{array}$ & $\mathbf{( N = 8 6 0 )}$ \\
\hline $\begin{array}{l}\text { Alt } \\
\text { Ölçekler }\end{array}$ & Cronbach Alpha & $\begin{array}{l}\text { Cronbach } \\
\text { Alpha }\end{array}$ & Cronbach Alpha \\
\hline RH &, 81 &, 78 &, 74 \\
SH &, 77 &, 79 &, 68 \\
ASH &, 69 &, 77 &, 93 \\
GRH &, 80 &, 66 &, 75 \\
İH &, 70 &, 71 &, 97 \\
DM &, 75 &, 73 &, 99 \\
BH &, 81 &, 84 &, 99 \\
FOS &, 85 &, 82 &, 94 \\
MAE &, 81 &, 79 &, 98 \\
\hline
\end{tabular}

\section{Test- Tekrar- Test Güvenirlik Sonuçlart}

ÇBÖ'nin test tekrar test güvenirliği için ikinci deneme uygulamasında yer alan 424 çocuktan oluşan çalışma grubunun içinden seçilen 121 çocuğa iki hafta sonra test tekrar uygulanmış ve sonuçlar Tablo 10'da verilmiştir.

Tablo 10. ÇBÖ Alt Ölçeklerinin İç Tutarlılık Katsayıları

\begin{tabular}{ll}
\hline Alt Ölçekler & r \\
\hline RH &, 75 \\
SH &, 74 \\
ASH &, 75 \\
GRH &, 59 \\
ISH &, 62 \\
DM &, 63 \\
BH &, 68 \\
FOS &, 83 \\
MAE &, 41 \\
\hline
\end{tabular}

Tablo 10'da görüldüğü gibi ÇBÖ alt ölçekleri için ile test-tekrar-test güvenirliği için Pearson Momentler Çarpımı Korelasyon Katsayısı hesaplanmıştır. Buna göre elde edilen değerler ,41 ile ,83 arasında değişmektedir ve ,01 düzeyinde manidardır. MAE alt ölçeğine yönelik devamlılık/kararlılık anlamında güvenirlik düzeyinin orta, diğer alt ölçeklerde ise yüksek düzeyde olduğu görülmektedir. Bu değerler ÇBÖ'ne ilişkin test tekrar yöntemine dayalı güvenirliğinin orta ve yüksek düzeyde olduğunu göstermektedir.

\section{Tartışma}

$\mathrm{Bu}$ çalışmada anasınıfından 4. sınıfa kadar olan dönemdeki çocukların çalışma belleği performanslarının değerlendirilmesine yönelik geliştirilen ÇBÖ’nin geçerlik ve güvenirlik düzeylerinin incelenmesi amaçlanmıştır. Bu kapsamda yapılan analizler sonucunda ÇBÖ'nin geçerli ve güvenilir bir araç olarak alanda uygulanabileceği sonucunda ulaşı1mıştır.

Ölçeğin yapı geçerliğine ilişkin yapılan AFA sonucunda her bir alt ölçek içerisindeki maddelerin faktör yük değerlerinin birinci deneme uygulamasında ,40 ile 92 arasında olduğu, ikinci deneme uygulamasında ise ,49 ile ,93 arasında olduğu görülmüştür. Bununla birlikte gerçekleştirilen DFA sonucunda ÇBÖ için sözel ve görsel olmak üzere iki bellek alanı, bu bellek alanlarına ilişkin dört alt boyut tanımlanmıştır. Elde edilen bu sonuçlar AWMA ile benzerlik göstermektedir. Ayrıca anasınıfı düzeyinde sözel belleğin en iyi yordayıcısının SH ve görsel belleğin en iyi yordayıcısının BH olduğu, 1. sınıf, 2. sınıf ve 4. sınıf düzeylerinde sözel belleğin en iyi yordayıcısının SH, görsel belleğin en iyi yordayıcısının FOS olduğu, 3.sınıf düzeyinde sözel belleğin en iyi yordayıcısının İSH ve görsel belleğin en iyi yordayıcısının BH olduğu bulunmuştur. 
Buna göre sınıf düzeylerinde ÇBÖ'nin uygulanması sonucunda gerek alt boyutlar düzeyinde, gerek sözel ve görsel bellek alanlarında ve gerekse ölçek genelinde elde edilecek toplam puanların geçerli ve değerlendirilebilir olduğu kararına varılmıştır. Bu sonuçlara göre ÇBÖ'nin yapı geçerliğinin yüksek olduğu belirlenmiştir. Bununla birlikte yapı geçerliği çalışmalarından sonra madde-toplam puan korelasyonları üzerinden ayırıcılık anlamında geçerlik çalışmaları yapılmış ve tüm alt ölçeklere ait madde toplam puan korelasyonları .01 düzeyinde manidar bulunmuştur. Ayrica esas uygulamada SH, İSH, DM, BH ve MAE alt ölçeklerinin madde toplam puan korelasyonlarının .40 'ın üzerinde olduğu ve ayırıcılıklarının yüksek olduğu görülmüştür. RH ve FOS alt ölçeklerinin 11. ve 12. maddelerinin madde toplam-puan korelasyonlarının deneme ve esas uygulamada da ,07 ile ,19 arasinda düşük olduğu ancak genel ortalamalarının yüksek olduğu görülmüş, her iki alt ölçekte de son iki maddenin yüksek beceri örüntülerine sahip olması, bu maddelere ulaşabilen çocuk sayısının az olması ve ayırıcılık anlamında genel ortalamalarının yüksek olması sebebiyle bu maddelerin ölçekte yer almalarına karar verilmiştir. Bu sonuçlar doğrultusunda ÇBÖ’nin ayırıcılığının yüksek olduğu düşünülmüştür.

ÇBÖ’nin ölçüt geçerliğini incelemek amacıyla geliştirilen Akademik Başarı Ölçeği, ,62 ile ,94 arasında değişen AFA değerleri ve ,01 düzeyinde manidar ve ,67'nin üzerindeki her alt ölçeklerine ait madde toplam puan korelasyonları ile yüksek geçerlik düzeyine ve ,71'in üzerinde hesaplanan yüksek güvenirlik düzeyine sahip olduğu bulunmuştur (Özgür-Yılmaz, 2016). Bununla birlikte, ÇBÖ'nin alt ölçeklerinden elde edilen toplam puanlar ile ölçüt puanları arasındaki korelasyonlar orta ve düşük düzeyde olmakla birlikte manidar olarak bulunmuştur. Standart akademik başarı ölçekleri kullanılarak çalışma belleği ile akademik başarı arasındaki ilişkiyi inceleyen araştırmalar incelendiğinde korelasyonların orta ve yüksek düzeylerde olduğu görülmektedir (Swanson, 1995; Thampson \& Gathercole, 2006). Bu çalışmada korelasyonların beklenenden daha düşük çıkmasının, likert tipi olan ve tamamen öğretmen görüşlerine dayanan Akademik Başarı Ölçeği’nin diğer çalışmalarda kullanılan standardize edilmiş başarı ölçeğinden farklılaşması ve çalışmada yer alan çocukların yaş grubu özellikleri ile ilişkili olduğu düşünülmüştür.

ÇBÖ test-tekrar-test güvenirliği için ölçek, çalışma grubunun içinden seçilen 121 çocuğa iki hafta sonra yeniden uygulanmış ve her alt ölçek için test-tekrar-test güvenirlik katsayıları hesaplanmıştır. Elde edilen korelasyon değerlerinin ,41 ile ,75 arasında değiştiği görülmüştür. Orta ve yüksek düzeyde çıkan anlamlı korelasyon değerleri ile test-tekrar-test güvenirlik değerleri kabul edilebilir düzeyde bulunmuştur. Bu bağlamda çalışmanın bulguları normal dağılım gösteren çocuklarla gerçekleştirilen diğer çalışmaların bulguları ile benzer bulunmuştur (Alloway vd., 2006, Dehn, 2008). Alloway ve diğerleri (2008) tarafından AWMA'nın güvenirliğini değerlendirmek için farklı iki zamanda yapılan test-tekrar-test çalışmasında ise, anlamsız sözcük hatırlama, desen matrisi ve mekansal ayırt etme için orta düzeyde korelasyonlar $(\mathrm{r}=, 51 \mathrm{r}=, 50 \mathrm{ve} \mathrm{r}=, 44)$ bulunurken, geriye rakam hatırlama için düşük korelasyon bulunmuştur $(\mathrm{r}=, 27)$. Bu çalışmada elde edilen değerlerin ise daha yüksek olduğu görülmüştür. Ayrıca Alloway ve diğerleri (2008) tarafindan en düşük korelasyon geriye rakam hatırlamada elde edilirken bu çalışmada DM'de elde edilmiştir $(\mathrm{r}=, 41)$. Elde edilen düşük korelasyonlar, yazarlar tarafından çalışmada yalnızca dört görev kullanılması ve seçilen tüm çocukların genelde düşük performans göstermeleri ile ilişkilendirilmiştir (Alloway vd., 2008). Ayrıca test yarılama yöntemi ile iç tutarlılık anlamında Cronbach Alpha katsayısı hesaplanmış ve ,66 ile ,84 arasında yüksek güvenirlik düzeyinde olduğu görülmüştür. Elde edilen bu bulgular, çalışma belleğini ölçmek amaciyla geliştirilen ölçeklerin güvenirlik düzeyleriyle benzer olduğu göstermiştir (Alloway vd., 2006; Dehn, 2008).

Analizler sonucunda ölçeğin geçerlik ve güvenirliğinin yeterli olduğu yönünde görüş oluşturulmasına rağmen sonuçlar değerlendirilirken çalışmaya ilişkin göz önünde bulundurulması gereken bazı sınırlılıklar da bulunmaktadır. İlk olarak, ÇBÖ’nin burada sunulan geçerlik ve güvenirlik verileri sadece Ankara ili merkezindeki ilkokullara devam eden ve normal gelişim gösteren çocuklar ile sınırlıdır. Bu açıdan, geçerlik ve güvenirlik verilerinin güçlendirilmesi amacıyla ölçeğin farklı illerden oluşturulmuş daha büyük ve farklı özelliklerdeki çocukları (özel gereksinimli çocuklar) içeren örneklem gruplarına uygulanması ve analizlerin tekrarlanması önerilmektedir. İkincisi ise ölçeğin ölçüt geçerliği için sadece çocukların öğretmenleri tarafından değerlendirilen akademik başarı performansları temel alınmıştır. Bu nedenle, çocukların ölçekten elde ettikleri puanların farklı gelişimsel alanlardaki performansları ve standardize edilmiş başarı ölçekleri ile değerlendirilen akademik performanslarıyla karşılaştırılarak ölçeğin ölçüt geçerliğinin yeniden incelenmesinin önemli olduğu düşünülmektedir.

Sonuç olarak, ÇBÖ'nin anasınıfından 4. sınıfa kadar olan dönemdeki çocukların çalışma belleği performanslarının belirlenmesinde geçerli ve güvenilir bir ölçme aracı olduğu ve ilgili alanyazın çerçevesinde ülkemizdeki alanyazına ve uygulamalara önemli katkılar sağlayacağı düşünülmektedir. Alanyazında sıklıkla belirtilen 
çalışma belleğinin okuma, okuduğunu anlama, yazma, matematik gibi akademik alanlarla olan ilişkisi göz önüne alındığında özellikle okul öncesi ve ilkokul dönemindeki çocukların çalışma belleği performanslarının değerlendirilerek çalışma belleği performanslarını arttırmaya yönelik müdahale çalışmalarına fayda sağlayacağı düşünülmektedir. Ayrıca çalışma belleğinde yaşanan sınırlılıkların özellikle öğrenmede yaşanan güçlükler ile ilişkilendirilmesi nedeniyle (Alloway vd., 2008) bu ölçek kullanılarak akademik başarısızlık ve öğrenme güçlüğü açısından risk grubunda değerlendirilen çocukların erken dönemde belirlenmesi ve müdahale programları ile olası başarısızlık risklerinin en aza indirilmesi mümkün olabilecektir. Ek olarak, ülkemizde çalışma belleğini değerlendirmeye yönelik araçların ve ilgili çalışmaların sınırlı olduğu göz önünde bulundurulduğunda, bu çalışma kapsamında geçerlik ve güvenirlik analizleri yapılan ÇBÖ’nin yeni yapılacak çalışmalara temel oluşturacağı ve öncülük edeceği öngörülmektedir. Bu açıdan uygulama alanının yaygın olacağı düşünülmektedir. 


\section{Extended Summary}

\section{Introduction}

Working memory is most often described as a three-component structure. According to the multi-component model of Baddaley and Hitch (1974), the working memory consists of the phonological loop and the visual-spatial sketchpad sub-systems and the central executive main function controlling these sub-systems. The phonological loop is defined as the limited capacity of temporary storage of verbal information. The visual-spatial sketchpad is a component that operates similarly to the phonological loop and stores the visual knowledge of the working memory for a short period of time. The central executive is the one that processes the information in these subsystems and coordinates all operations in the working memory. In addition to these three structures in the multi-component model, a fourth component, called the episodic buffer, was added in the following years to explain the interaction between the working memory and the long-term memory.

Working memory is a very influential structure that affects the whole learning experience of the individual. Numerous studies have indicated that there is a strong relationship between working memory performance and language development, reading, reading comprehension, writing and mathematics achievement. Also it has been found that children who are inadequate in their language and academic skills have more limited working memory capacity and can process and store the information more slowly and insufficiently than their normal developing peers. In this respect, it is important to assess the working memory performance of children so that those with inadequate working memory performance can be identified early and supported by intervention programs.

In this study, it was aimed to examine the reliability and validity of the Working Memory Scale (WMS) developed to determine the performance of working memory for children in the age group of 5-10 years. The scale includes nine subtests in total four dimensions as verbal / visual short-term memory and verbal / visual working memory. Verbal short- term memory is evaluated by Digit Recall, Word Recall, Nonword Recall subscales. Visual short- term memory is evaluated by Dot Matrix and Block Recall subscales. Verbal working memory is evaluated by Backward Digit Recall and First Word Recall subscales. Finally, Visual Working memory is evaluated by Odd-OneOut and Spatial Span subscales. Each subscale consists of items containing increasing numbers of sequences and two trials. During the application of the subscales, the sequences in each of the items are presented sequentially to the child, the child is asked to repeat the figures they hear or see in the same or reverse order. If the child succeeds in at least one of the trials in each item, it can be passed to the next item. In case of failure in both trials, the subscale is terminated.

\section{Method}

A correlational model from relational screening models was used in the study. A total of 1494 children constituted the sample, 634 of whom were involved in the two trial stages and 860 were involved in the main application. All children were administered the WMS. Content validity of the scale was examined by means of expert opinions. To determine the construct validity, a principal component analysis, a cluster analysis and a confirmatory factor analysis were performed. For the discriminant validity, point-biserial correlation coefficients and the item-total score correlations were calculated. Academic Achievement Scales were used for criterion validity. In order to determine the test-retest reliability, a Pearson product-moment correlation coefficient was calculated while a Cronbach's alpha internal consistency coefficient was calculated for the split-half reliability.

\section{Results}

Principal component analysis of the construct validity of the scale showed that the factor load values of the items in each subscale were between ,40 and ,92 for the first trial application and between, 49 and ,93 for the second trial application. In order to support the principal component analysis, a cluster analysis was performed for some of the subscales on the first and second trial data, and necessary improvements were provided. As a result of the exploratory and confirmatory analyses, the number of items of each subscale is arranged so that high structure validity is obtained. As a result, the structure related to the WMS is verified by the principal component analysis conducted on the trials' data, and confirmed with the confirmatory factor analysis conducted on the main application data. The correlations between the academic achievement scale developed to examine the criterion validity and the total scores obtained from the WMS were found to be moderate and low. Test-retest reliability coefficients were calculated, and found 
varied from ,41 to ,75. In addition, the Cronbach Alpha coefficient for internal consistency was calculated by the splithalf reliability method and it was found to be between ,66 and ,84 at high reliability level.

\section{Discussion}

The findings of the study show that the Working Memory Scale can be used in the field as a valid and reliable tool. Results are comparable to the previous findings. However, there are some limitations to be considered when considering the results. Firstly, the reliability and validity of this scale presented here is limited only to those who are typically developing and attending primary schools in Ankara. Secondly, the criterion validity is based only on the academic achievement performance assessed by the teachers of the children. Nevertheless, considering that the tools and related studies for evaluating the working memory in Turkey are limited, it is foreseen that the WMS, whose validity and reliability analyzes are conducted within the scope of this study, will form a basis for future studies. 


\section{Kaynakça / References}

Adams, W., \& Sheslow, W. (2003). Wide range assessment of memory and learning (2nd ed.). Wilmington, DE: Wide Range.

Akoğlu, G. (2011). Gelişimsel dil bozukluğu olan ve normal gelişim gösteren çocuklarda sözdizimini anlama becerileri ile sözel çalışma belleği ilişskisinin incelenmesi (Yayınlanmış yüksek lisans tezi). Ankara Üniversitesi, Ankara.

Akoğlu, G., \& Acarlar, F. (2014). Gelişimsel dil bozukluklarında söz dizimi anlama ve sözel çalışma belleği ilişkisinin incelenmesi. Türk Psikoloji Dergisi, 29 (73), 89-103.

Alloway, T. P., \& Alloway R. (2010). Investigating the predictive roles of working memory and IQ in academic attainment. Journal of Experimental Child Psychology, 106, 20-29.

Alloway, T. P., \& Archibald, L. M. D. (2008). Working memory and learning in children with developmental coordination disorder and specific language impairment. Journal Of Learning Disabilities, 3, 251- 262.

Alloway, T. P., Gathercole, S. E., Kirkwood, H., \& Elliott, J. (2008). Evaluating the validity of the automated working memory assessment. Educational Psychology, 28(7), 725-734.

Alloway, T. P., Gathercole, S. E., \& Pickering, S. J. (2006). Verbal and visuospatial short-term and working memory in children: Are they separable?. Child development, 77(6), 1698-1716.

Alloway, T. P., Gathercole, S. E., Willis, C., \& Adams, A. M. (2004). A structural analysis of working memory and related cognitive skills in young children. Journal of experimental child psychology, 87(2), 85-106.

Alp, E., \& Özdemir, B. (2007). Çocuklarda akıcı zekanın (gf) bilgi işleme hızı, kısa süreli bellek ve çalışma belleği kapasitesi ile ilişkisi. Türk Psikoloji Dergisi, 22 (60), 1-15.

Altun, A., \& Çevik, V. (2012). Çoklu ortam tabanlı bir görev ile çalışma belleğinin ölçülmesi. Hacettepe Üniversitesi Eğitim Fakültesi Dergisi, Özel Sayı 1, 32-40.

Archibald, L. M., \& Gathercole, S. E. (2006). Visuospatial immediate memory in specific language impairment. Journal of Speech, Language, and Hearing Research, 49(2), 265-277.

Babayiğit, S., \& Stainthorp, R. (2009). Component processes of early reading, spelling, and narrative writing skills in Turkish: A longitudinal study. Read Writ, 23, 539- 568.

Babayiğit, S., \& Stainthorp, R. (2011). Modeling the relationships between cognitive-linguistic skills and literacy skills: New insights from a transparent orthography. Journal of Educational Psychology, 1, 169- 189.

Baddeley, A., \& Wilson, B. A. (1994). When implicit learning fails: Amnesia and the problem of error elimination. Neuropsychologia, 32(1), 53-68.

Baddeley, A. (1996). Exploring the central executive. The Quarterly Journal of Experimental Psychology: Section A, 49(1), 5-28.

Baddaley, A. (2000). The episodic buffer: a new component of working memory. Trends in Cognitive Sciences, 11, 417- 422.

Baddaley, A. (2006). Working memory: An overview. In S. Pickering (Ed.), Working memory and education (pp. 1-31). New York, NY: Academic Press.

Baddeley, A. (2007). Working memory, thought, and action. Oxford: Oxford University Press.

Baddeley, A., Gathercole, S., \& Papagno, C. (1998). The phonological loop as a language learning device. Psychological Review, 105(1), 158.

Baddeley, A. D., \& Hitch, G. (1974). Working memory. Psychology of learning and motivation, 8, 47-89.

Baddaley, A., \& Hitch, G. J. (1994). Developments in the concept of working memory. Neuropsychology, 4, 485-493.

Baddaley, A., \& Logie, R. H. (1999). Working memory: The multiple component model. In A. Miyake \& P. Shah (Eds.), Models of working memory: Mechanisms of active maintenance and executive control (pp. 28-61). Cambridge: Cambridge University Press.

Berninger, V. W., \& Richards, T. L. (2002). Brain literacy for educators and psychologists. New York, NY: Academic Press. 
Bull, R., \& Scerif, G. (2001). Executive functioning as a predictor of children's mathematics ability: Inhibition, switching, and working memory. Developmental Neuropsychology, 19(3), 273-293.

Ciappe, P., Hasher, L., \& Siegel, L. (2000). Working memory, inhibitory control and reading disability. Memory and Cognition, 28(1), 8-17.

Clair-Thompson, L. H., \& Gathercole, S. E. (2006). Executive functions and achievements in school: Shifting, updating, inhibition, and working memory. The Quarterly Journal of Experımental Psychology, 59(4), 745-759.

Cohen, M. (1997). Children's Memory Scale (CMS). San Antonio, TX: Psychological Corporation.

Crain, S., Shankweiler, D., Macaruso, P., \& Bar-Shalom, E. (1990). Working memory and comprehension of spoken sentences: Investigations of children with reading disorder. In G. Vallar \& T. ShaIlice (Eds.), Neuropsychological impairments of short-term memory (pp. 477-508). Cambridge: Cambridge University Press.

Çokluk, Ö., Şekercioğlu, G., \& Büyüköztürk, Ş. (2016). Sosyal bilimler için çok değişkenli istatistik: SPSS ve LISREL uygulamalart. Ankara: Pegem Akademi.

Dehn, M. (2008). Working memory and academic learning: Assessment and intervention. Hoboken, NJ: John Wiley and Sons.

Dehn, M. (2010). Long-term memory problems in children and adolescens: Assessment, intervention and effective instruction. Hoboken, NJ: John Wiley and Sons.

De Weerdt, F., Desoete, A., \& Roeyers, H. (2013). Working memory in children with reading disabilities and/or mathematical disabilities. Journal of learning disabilities, 46(5), 461-472.

Doğan, M. (2011). Işsitme kayıplı çocukların ve normal işiten çocukların çalışma belleği ve kısa süreli bellek yönünden incelenmesi (Yayınlanmamış doktora tezi). Anadolu Üniversitesi, Eskişehir.

Engle, R. W. (1996). Working memory and retrieval: An inhibition-resource approach. In J. T. E. Richardson, R. W. Engle, L. Hasher, R. H. Logie, E. R. Stoltzfus, \& R. T. Zacks (Eds.), Working memory and human cognition (pp. 89-119). New York, NY: Oxford University Press.

Engle, R. W. (2002). Working memory capacity as executive attention. Current directions in psychological science, 11(1), 19-23.

Gathercole, S. E. (1999). Cognitive approaches to the development of short-term memory. Trends in Cognitive Sciences, 3(11), 410-419.

Gathercole, S. E., Alloway, T. P., Willis, C., \& Adams, A. (2006). Working memory in children with reading disabilities. Journal of Experimental Child Psychology, 93(3), 265-281.

Gathercole, S. E., Brown, L., \& Pickering, S. J. (2003). Working memory assessments at school entry as longitudinal predictors of National Curriculum attainment levels. Educational and Child Psychology, 20(3), 109-122.

Gathercole, S. E., \& Pickering, S. (2000). Working memory deficits in children with low achievements in the national curriculum at 7 years of age. British Journal of Educational Psychology, 70, 177-194.

Gathercole, S. E., Pickering, S., Knight, C., \& Stegmann, Z. (2004). Working memory skills and educational attainment: Evidence from national curriculum assessments at 7 and 14 years of age. Applied Cognitive Psychology, 18,1-16.

Geary, D. C., Hoard, M. K., Byrd-Craven, J., Nugent, L., \& Numtee, C. (2007). Cognitive mechanisms underlying achievement deficits in children with mathematical learning disability. Child Development, 78(4), 1343-1359.

Harrison, T. L., Shipstead, Z., \& Engle, R. W. (2015). Why is working memory capacity related to matrix reasoning tasks?. Memory ve Cognition, 43(3), 389-396.

Holmes, J., \& Adams, J. (2006). Working memory and children's mathematical skills: Implications for mathematical development and mathematics curricula. Educational Psychology, 3, 339-366.

Hu, Y., Hitch, G. J., Baddaley, A.D., Zhang, M., \& Allen, R. J. (2014) Executive and perceptual attention play different roles in visual working memory: Evidence from suffix and strategy effects. Journal of Experimental Psychology, 4, $1665-1678$. 
Jerman, O., Reynolds, C., \& Swanson, H. L. (2012). Does growth in working memory span or executive processes predict growth in reading and math in children with reading disabilities? Learning Disability Quarterly, 35(3), 144-157.

Kafadar, H. (2004). Akıcı zekanın performans zeka, sözel zeka, yönetici işlevler, çalışma belleği, seçici dikkat ve kısa süreli bellek süreçlerinden yordanması (Yayınlanmamış doktora tezi). Hacettepe Üniversitesi, Ankara.

Karakelle, S., \& Ertuğrul, Z. (2012). Zihin kuramı ile çalışma belleği, dil becerisi ve yönetici işlevler arasındaki bağlantılar küçük (36-48ay) ve büyük (53-72ay) çocuklarda farklılık gösterebilir mi? Türk Psikoloji Dergisi, 27(70), 1-21.

Kesikçi, H., \& Amado, S. (2005). Okuma güçlüğü olan çocukların fonolojik bellek, kısa süreli bellek ve WISC-R ölçeği puanlarına ait bir inceleme. Türk Psikoloji Dergisi, 20(55), 99-110.

Kroesbergen, E. H., Van’t Noordende, J. E., \& Kolkman, M. E. (2012). Training working memory in kindergarten children: Effects on working memory and early numeracy. Child Neuropsychology, 1, 23-37.

Mammarella, I. C., Lucangeli, D., \& Cornoldi, C. (2010). Spatial working memory and arithmetic deficits in children with nonverbal learning difficulties. Journal of Learning Disabilities, 43(5), 455-468.

Marton, K., \& Eichorn, N. (2014). Interaction between working memory and long-term memory: A study in children with and without language impairment. Zeitschrift Für Pyschologie, 2, 90- 99.

Nyman, A., Taskinen, T., Grönroos, M., Haataja, L., Lähdetie, J., \& Korhonen, T. (2010). Elements of working memory as predictors of goal-setting skills in children with attention-deficit/hyperactivity disorder. Journal of Learning Disabilities, 43(6), 553-562.

Özgür Yılmaz, Ç. (2016). 5-10 yaş grubu çocuklara yönelik çalışma belleği ölçeğinin geçerlik-güvenirlik çalışması (Yayınlanmamış yüksek lisans tezi). Ankara Üniversitesi, Ankara.

Peng, P., \& Fuchs, D. (2017). A Randomized control trial of working memory training with and without strategy instruction: Effects on young children's working memory and comprehension. Journal of Learning Disabilities, 50(1), 62-80.

Passolunghi, M. C., \& Siegel, L. S. (2004). Working memory and access to numerical information in children with disability in mathematics. Journal of Experimental Child Psychology, 88, 348-367.

Pickering, S. J., Gathercole, S. E., Hall, M., \& Lloyd, S. A. (2001). Development of memory for pattern and path: Further evidence for the fractionation of visuo-spatial memory. The Quarterly Journal of Experimental Psychology: Section A, 54(2), 397-420.

Pimperton, H., \& Nation, K. (2014). Poor comprehenders in the classroom: teacher ratings of behavior in children with poor reading comprehension and its relationship with individual differences in working memory. Journal of learning disabilities, 47(3), 199-207.

Rajendran, G., Alloway, T. P., \& Archibald, L. (2009). Working memory in children with developmental disorders. Journal of Learning Disabilities, 42(4), 372-382.

Reynolds, C. R., \& Voress, J. K. (2007). Scale of Memory and Learning (2nd ed.). Austin, TX: PRO-ED.

Ricker, T. J., \& Cowan, N. (2014). Differences between presentation methods in working memory procedures: A matter of working memory consolidation. Journal of Experimental Psychology: Learning, Memory, and Cognition, 40(2), 417-428.

Sayar, F., \& Turan, F. (2012). Okuma gelişiminde üst dil farkındalığı, ses bilgisel süreçler ve bellek süreçlerinin etkisi: Kısa süreli bellek ve çalışma belleği. Ankara Üniversitesi Eğitim Bilimleri Fakültesi Özel Ĕ̆itim Dergisi, 13(2), 49-64.

Schweppe, J., \& Rummer, R. (2014). Attention, working memory, and long-term memory in multimedia learning: an integrated perspective based on process models of working memory. Educational Psychology Review, 26(2), 285-306.

Service, E. (1992). Phonology, Working Memory, and Foreignlanguage Learning. The Quarterly Journal of Experımental Psychology, 45(1) 21-50.

Swanson, H. L. (1995). Effects of dynamic ölçeğing on the classification of learning disabilities: The predictive and discriminant validity of the Swanson-Cognitive Processing Scale (S-CPT). Journal of Psychoeducational Assessment, 13(3), $204-229$.

Swanson, H. L. (2000). Are working memory deficits in readers with learning disabilities hard to change. Journal of Learning Disabilities, 6, 551- 566. 
Swanson, H. L. (2001). Research on interventions for adolescents with learning disabilities: A meta-analysis of outcomes related to higher-order processing. The Elementary School Journal, 101(3), 331-348.

Swanson, H. L. (2006). Working memory and dynamic scale for children with learning disabilities. In S. Pickering (Ed.), Working memory and education. (pp. 125-156). New York, NY: Academic Press.

Swanson, H. L. (2011). Dynamic ölçeğing, working memory, and reading comprehension growth in children with reading disabilities. Journal of Learning Disabilities, 44(4), 358-371.

Swanson, H. L., Kehler, P., \& Jerman, O. (2010). Working memory, strategy knowledge, and strategy instruction in children with reading disabilities. Journal of Learning Disabilities, 43(1), 24- 47.

Swanson, H. L., \& Sachse-Lee, C. (2001). Mathematical problem solving and working memory in children with learning disabilities: Both executive and phonological processes are important. Journal of Experimental Child Psychology, 79(3), 294-321.

Tercan, E., Ergin, H., \& Amado, S. (2012). Okuma güçlüğü yaşayan çocuklarda çalışma belleğinin fonolojik depo açısından incelenmesi. Türk Psikoloji Dergisi, 27(69), 65-75.

Torn, A., \& Page, M. (2009). Interactions between short-term and long-term memory in the verbal domain. New York, NY: Psychology Press.

Turgut, M. F., \& Baykul, Y. (2010). Ĕgitimde ölçme ve değerlendirme. Ankara: Pegem Akademi.

Urbina, S. (2004). Essentials of pyschological scales. Hoboken, NJ: John Wiley ve Sons.

Wechsler, D. (1997). WMS-III: Wechsler memory scale administration and scoring manual. San Antonio, TX: Psychological Corporation.

Yalın, A., \& Karakaş, S. (1994). Görsel İşitsel Sayı Dizisi Ölçeği A Formunun bir Türk çocuk örnekleminde güvenirlik, geçerlik ve standardizasyon çalışması. Türk Psikoloji Dergisi, 9(32), 6-14. 